\title{
ISMAIIL BEY GASPIRALI'NIN ALİ MERDAN TOPÇUBAŞI'NA YAZDIĞI MEKTUPLAR
}

\section{Rıdvan ÇíTíL*}

\begin{abstract}
Öz
Rusya Müslümanlar1-Türkleri hakkında bilinmeyenler, araştırmacılar arasında her geçen gün daha çok merak uyandırmaktadır. Bu konuda, yeni belgeler gün yüzüne çıkmakta ve birçok çalışmalar yapılmaktadır. $\mathrm{Bu}$ makalemizde 1904-1910 yılları arasında cereyan eden siyasî, kültürel vb. olayları o dönemin en önde gelen aydın, lider ve maarifçilerinden biri olan İsmail Bey Gaspıralı'nın Azerbaycanlı avukat, yazar, gazeteci ve siyaset adamı Ali Merdan Topçubaşı'na yazdığı yedi adet mektuptan takip etme imkânını bulacağız. Böylece o dönemle ilgili en ince ayrıntıları yakalamış ve bazı bilinmeyenleri birinci ağızdan öğrenmiş olacağız.
\end{abstract}

Anahtar Sözcükler: Türk Dünyası, Rusya Müslümanlar1-Türkleri, İsmail Gaspıralı, Ali Merdan Topçubaşı (Topçubaşev), Türk Dünyası Kültür Hayatı.

\section{THE LETTERS WRITTEN BY ISMAIL BEY GASPRINSKIJ TO ALI MERDAN BEY TOPCHUBASHI}

\begin{abstract}
Unknowns about Russian Muslims-Turks day by day become more and more curious. In this issues, appear new documents and studies are carried out. When it comes to correspondence of Ismail Gasprinski and other intellectuals and the author of the Turkic World the importance of these documents rises one more time. In this study we will have possibility to follow up the political, cultural and so on events that took place between the years 1904-1910, from seven letters whom write one of the leading intellectuals of the authority of that era, one of the leaders and educator Ismail Bey Gasprinski to Azerbaijani lawyer, author, journalist Ali Merdan Topçubashi. So we caught the finest details about that period and will learn unknowns from the first person.
\end{abstract}

Keywords: Turkic World, Muslims- Turks of Russia, Ismail Gasprinski, Ali Merdan Topchubashi (Topchubashev), Turkic World Culture Life.

\section{Giriş}

Her geçen günle birlikte Türk Dünyası ve onun önde gelenleri hakkında yapılan çalışmalar artmaktadır. Çalışmaların çoğalmasıyla birlikte birçok bilinmeyen ve yıllarca aydınlatılması beklenen bilgi ve belgeler araştırılarak ortaya çıkartılmaktadır. Rusya Müslümanlarının-Türklerinin öncülerinden biri olan Gaspıralı İsmail Bey’in Türk Dünyası tarihindeki yeri ve etkisi, her ne kadar Çarlık yönetimi onu engellemeye çalışmışsa da, büyük olmuştur. Bu yüzden onun yolundan giden Türk boylarının bazı aydınları 1926-1937 yılları

* Okt. Dr.; Mehmet Akif Ersoy Üniversitesi Gölhisar Meslek Yüksekokulu, ridvan571@ hotmail.com. 
arasında Sovyet yönetimi tarafından sürgün edilerek veya katledilerek ortadan kaldırılmıştır. Böylece Sovyetler Birliği döneminde İsmail Bey’in çalışmalarına, düşüncelerine ve şahsına karş1 duyulan ilgi tamamen olmasa da büyük ölçüde perdelenmiştir. Sovyetler Birliği’nin dağılmasından sonra İsmail Gaspıralı ve düşüncelerine duyulan ilgi günden güne artmış ve artmaktadır. Sovyetler Birliği dışında ise İsmail Gaspıralı'ya ilgi hiç azalmamış, aksine her geçen gün İsmail Gaspıralı ve onun fikir, ideal ve çalışmaları yeniden araştırılıp gün yüzüne çıkartılmış ve çıkartılmaya devam etmektedir. Özellikle de onun hakkında Türkiye, Kırım, Batı dünyası ve Rusya Federasyonu'nda birçok araştırma yapılmış ve yapılmaktadır. İsmail Gaspıralı'nın vefatının 100. yılı dolayısıyla 2014 yılı UNESCO tarafından İsmail Gaspıralı'yı anma yılı olarak kabul edilmiş ve İ. Gaspıralı ile ilgili birçok etkinlik düzenlenerek onun hayatı, çalışmaları, fikir, düşünce ve eserlerine dikkat çekilmiş ve çekilmeye devam edilmektedir.

Bilindiği gibi Türk Dünyası'nın önde gelen aydın, eğitimci, yayıncı ve maarifçisi olan Gaspıralı (Gasprinskiy) İsmail Bey (1851-1914), usul-i savtî metoduyla, Arap alfabesini okumayazmayı öğreten okullar açarak, ders kitapları yazarak eğitim alanında birçok yeniliklere imza atmıştır. Rusya Müslümanlarının millî-kültürel alanda yeniden doğuşuna öncülük etmiştir. En önemli icraatlarından biri de 1883 yılından itibaren Bahçesaray'da yayımlamaya başladığ 1 edebî-siyasî ve bilimsel Tercüman (Perevodçik) gazetesidir. Çünkü bu gazete Çin sınırından Adriyatik Denizi'ne kadar olan geniş bölgeye ulaşmış ve Rusya Müslümanlarının-Türklerinin, hatta Osmanlı Devleti'nde dahi birçok kimsenin bilgilenmesini ve uyanışını sağlamıştır. İsmail Gaspıralı Tercüman gazetesini vefatına kadar çıkarmış, vefatından sonra da çocukları ve dostları 1918 yılına kadar çıkarmaya devam etmişıerdir. Ayrıca İsmail Gaspıralı, 1905-1906 yıllarında kurulan Rusya Müslümanlarının İttifak-1 Müslimin Partisi'nin Merkezî Komite'nin de üyesi olmuştur. ${ }^{1}$

Türk Dünyası ve Rusya Müslümanlarının bir diğer önemli şahsiyetlerinden biri de hiç şüphesiz Ali Merdan Bey Topçubaşı'dır (1865-1934). Azerbaycan Türklerinden olan A. M. Topçubaşı, Petersburg Üniversitesi'nde hukuk eğitimi almış ve mezun olduktan sonra Rusya Müslümanları için avukat olarak büyük hizmetler ifa etmiştir. Gazetecilik alanında da faaliyet göstererek bir dönem Kaspiy gazetesinin redaktörlüğünü yapmıştır. Rusya Müslümanları Kongreleri'nin düzenlenmesinde ve İttifak'ın kuruluş çalışmalarında önemli görevlerde bulunmuştur. Çarlık Rusya'nın I. Devlet Duması'na milletvekili seçilmiş, Azerbaycan Demokratik Cumhuriyeti'nin (1918-1920) kurucuları arasında yer almıştır. Azerbaycan Demokratik Cumhuriyeti’nin Parlamento Başkanı ve Dış İşleri Bakanı (1918) gibi görevleri de

\footnotetext{
${ }^{1}$ İsmail Gaspıralı'nın hayatı, eserleri, fikirleri ve çalışmaları hakkında daha fazla bilgi için bakınız: İsmail Gaspıralı, Seçilmiş Eserleri, 1, 2, 3. Neşre Hazırlayan: Yavuz Akpınar, Ötüken Yayınevi, İstanbul, 2003-2014. 
başarıyla yürütmüştür. Azerbaycan Cumhuriyeti'ni temsil etmek için Paris Sulh Konferansı'na gönderilen heyetin başkanlığına getirilmiş ve ömrünün sonlarına kadar muhacerette yaşayarak ülkesi ve milleti adına elinden gelenin en iyisini yapmaya çalışmıştır. ${ }^{2}$

Bu makalemizde, İsmail Gaspıralı'nın Ali Merdan Topçubaşı'na yazdığı yedi adet mektup Rusçadan tercüme edilerek incelenmiştir. Bu mektuplardan beşini, Salavat Midhatoğlu İshakov ${ }^{3}$ Azerbaycan Cumhuriyeti'nin devlet arşivindeki çalışması sırasında bulmuş ve bunları Rusça el yazısından deşifre ederek bize taranmış resimleriyle birlikte göndermiştir. Bu yedi mektuptan "11 Sentyabr 1906” tarihli olanının tıpkıbasımına ise Ş. Hablemitoğlu ile N. Hablemitoğlu'nun “Şefika Gaspıralı ve Rusya'da Türk Kadın Hareketi (1893-1920)” adlı kitabını incelerken rastladım ve el yazısından deşifre etmesi için S. M. İshakov'a gönderdim. Kendisi bu mektubu da deşifre ederek bize gönderdi ve A. M. Topçubaşı hakkında çıkardığ 1 kitabında ${ }^{4}$ bulduğu diğer mektup ve belgelerle birlikte kullanmıştır.

Ayrıca İstanbul Üniversitesi Türk Dili okutmanı Halil Açıkgöz, zamanında İstanbul'da Şefika Gaspıralı'nın kızı Zühre Gökgöl Hanımefendi’den İsmail Gaspıralı'nın kızı ve damadına yazdığı mektuplar ve evlilik senedinin fotokopisini temin etmişti. Aradan yıllar geçtikten sonra bunları yayımlaması için hocam Yavuz Akpınar'a vermiş, o da bunların tercümesini Kars’taki Kafkas Üniversitesi öğretim üyelerinden Prof. Dr. Hacali Necefoğlu'ndan rica etmişti. Hacali Bey'in tercüme ettiği bu belge ve mektuplar Ege Üniversitesi Edebiyat Fakültesi Türk Dili ve Edebiyatı Araştırmaları Dergisi'nin 23. sayısında yayımlanmıştır. ${ }^{5}$ Bu belge ve mektuplar arasındaki İsmail Gaspıralı'nın Ali Merdan Topçubaşı'na yazdığı “11 Aprel 1908” tarihli mektubu bu araştırmamızda tekrar yayımlamayı uygun gördük. Bu "11 Aprel 1908" tarihli mektup dışındaki diğer mektupların Rusçadan tercümeleri ise tarafımızdan yapılmış, her biri teker teker incelenerek burada değerlendirilmiştir. Mektuplardaki açıklamalar hem tarafımızdan kaynakçada verilen eserlere başvurularak yapılmış hem de S. M. İshakov'un kitabında yaptığ 1 açıklamalar, tercüme edilerek gerekli ölçüde kullanılmıştır. Ayrıca mektupların el yazılı orijinal metinlerin kopyasını da tercümeleriyle birlikte ilk defa burada yayımlıyoruz. Çalışmamızda inceleyeceğimiz mektuplardaki ayların isimleri ve tarihler Rus Ortodoks takvimine göredir.

\footnotetext{
${ }^{2}$ Ali Merdan Topçubaşı'nın hayatı, eserleri, fikirleri ve çalışmaları hakkında daha fazla bilgi için bakınız: $A$. M. Топчибаши. Документы из личных архивов. 1903-1934, С. М. Исхаков, Издательство “Социальнополитическая МЫСЛЬ”, Москва 2012; Cəmil Həsənli, Tarixi Şəxsiyyətin Tarihi. Olimərdan bəy Topçubaşov, Azəbaycan Diplomatik Akademiyas1, Bak1, 2013; Джамиль Гасанлы, Али Мардан-Бек Топубашев, Жизнь За Идею, Издательство Флинта, Издательство Наука, Москва, 2014.

${ }^{3}$ Dr. Salavat Midhatoğlu İshakov (d. 1959): Tarihçi, Rusya Bilimler Akademisi’nin Rusya Tarihi Enstitüsü'nün Kıdemli Araştırmacısı, Rusya Bilimler Akademisi'nin Sosyal Reform, Hareketler ve İhtilâller Tarihi Bilim Konseyi'nin Akademik Sekreteri.

${ }^{4}$ С. М. Исхаков, А. М. Топчибаши. Документы из личных архивов. 1903-1934, Издательство “Социальнополитическая МЫСЛЬ”, Москва 2012.

${ }^{5}$ Daha fazla bilgi için bakınız: Rıdvan Çitil, Hacali Necefoğlu, İsmail Gaspıralı'nın Neşredilmemiş Bazı Mektupları, Ege Üniversitesi Edebiyat Fakültesi Türk Dili ve Edebiyatı Araştırmaları Dergisi, Sayı 23, s. 13-43. İzmir, 2014.
}

\section{TFipe}


Bunları Miladi takvime çevirmek için söz konusu tarihlere 13 gün eklenmiş ve ayların adları köşeli parantez içinde gösterilmiştir.

\section{Belge 1: İsmail Gaspıralı'nın Ali Merdan Topçubaşı'na yazdığı Dekabr [Aralık] 1904 tarihli} mektup ve tercümesi:

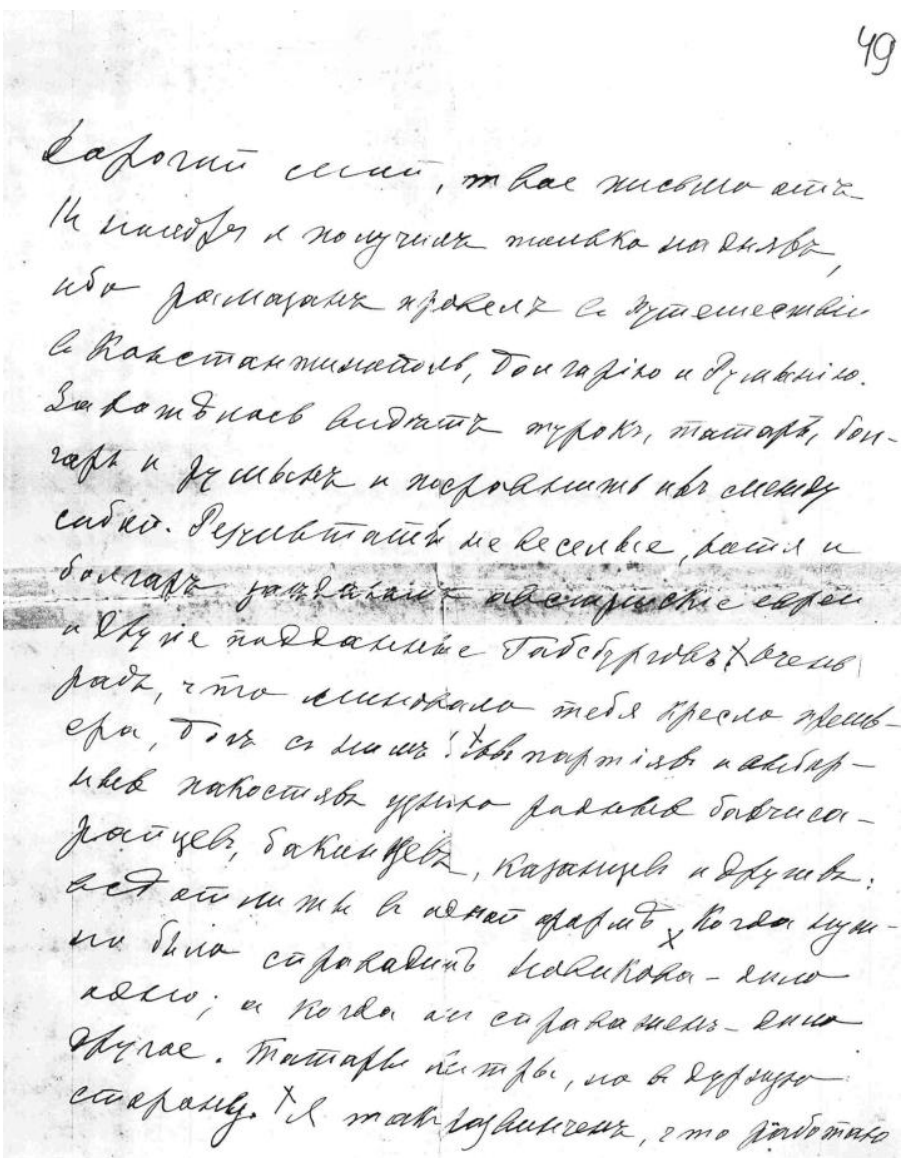

Dekabr [Aralık] $1904^{6}$

[Bahçesaray]

Azizim, 14 Noyabr [27 Kasim] tarihli mektubunu, Ramazan ${ }^{7}$ ayinı İstanbul, Bulgaristan ve Romanya'da seyahatte ${ }^{8}$ geçirdiğim için daha bugünlerde aldım. Türkleri, Tatarlarl, Bulgarları ve Romenleri görmek ve bunları birbirleriyle karșılaștırmak istedim. Avusturyalı Yahudiler ve Habsburglar'a ${ }^{9}$ tâbi diğer milletlerin Bulgarları ele geçirmelerine rağmen sonuçlar iyi değil. Başkanlık koltuğunun ${ }^{10}$ seni ıskaladığına çok sevindim. Aldırış etme! Partilerde ve seçilmişlerin yaptı̆̆ pisliklerde yerli Bahçesaraylıları, Bakûluları, Kazanlıları ve diğerlerini tanlyabiliyorum: Sanki hepsi bir kalıptan çıkmış. Novikov'u' uğurlamak gerekirken bir mesele; uğurlandiktan sonrası da başka bir meseledir.

\footnotetext{
${ }^{6}$ İsmail Gaspıralı bu mektupta tarih vermediği için tarih mektup metninin içeriğine göre verilmiştir.

${ }^{7} 1904$ senesinde Ramazan ayı, 9 Kasım-9 Aralık 1904 tarihleri arasında olmuştur.

${ }^{8}$ İsmail Gaspıralı'nın bu seyahati hakkında herhangi bilgi bulunamamıştır.

${ }^{9}$ Habsburglar: 1282-1918 yılları arasında Avusturya'yı yöneten hanedan.

${ }^{10}$ Burada İran şahı Müzaferüddin tarafından A. Merdan Bey’e başbakanlık yapması için yapılan tekliften söz edilmektedir (Həsənli, 2013: 115-116).

11 Aleksandr İvanoviç Novikov (1861-1913): Rus devlet adamı. Moskova'daki Katkov Lisesi’ni 1878 yılında, Moskova Üniversitesi Fizik-Matematik Fakültesi'ni de 1882 yılında bitirmiştir. Kozlovsk, Kafkasya, Kırım ve Astırhan gibi yerlerde çeşitli devlet görevlerinde bulunmuş ve 1902-1904 yılları arasında da Bakû şehrinin belediye
} 
Tatarlar kurnazlar, ama kötü yönden. Ben çok yoruldum ve bu yüzden gücümü dikkatle kullanarak çok az çallşlyorum. Ne yazlk ki işbirliği konusunda sana söz veremem, ama yine de bir şey yazmayl düşünüyorum. Tatarların dikkatini ve muhabirleri daha da çekmek için "Kaspi",12 hakkinda "Perevodçik"te ["Tercüman"da] ${ }^{13}$ yazı yazacağım. Endişelenme, bunu zararsız bir biçimde yapacağım. "Şark-i Rus"," hakkinda nasll istersen; "mülkiyet" olarak bir yük olmaz. Ancak, pek acele etmeye de gerek yok, "belki" bir gün basın özgürlüğünü görürüz ve o zaman "Ş[ark-i] Rus"u bir tarafa bırakarak yeni bir gazeteye girişiriz. Lemanov'a ${ }^{15}$ bel bağlama diye sana daha önce yazmıştım; o sıradan bir yazar değildir; onu başka bir alan için hazırllyoruz. O, bizim din alimlerinin arkaik öğretim yöntemlerini yeniden düzenlemek için Arapça kursu açmaya hazırlanıyor. Bakalım, bundan ne çıkacak. Herkese sayglar.

Vefall İsmail.

$\mathrm{Bu}$ mektupta İsmail Gaspıralı ile Ali Merdan Topçubaşı arasındaki samimi, dostane ilişki ve birbirine olan destek dikkatimizi çekmektedir. Bu durum, birbirine olan hitap şeklinden ve onurlandırıcı sözlerden anlaşılmaktadır. Bir diğer husus ise İ. Gaspıralı'nın seyahate çıkarak İstanbul, Bulgaristan ve Romanya'da gözlemlerde bulunmasıdır. Böylece o dönemin sosyal hayatı ve insanları hakkındaki tespitleri birinci ağızdan öğrenmiş oluyoruz. Bilindiği gibi o dönemde uzun yıllar Rusya Müslümanlarının-Türklerinin gazetesi olan Tercüman yanında Şark$i$ Rus gazetesi pek uzun ömürlü olmamış ve mektubun yazıldığ 1 tarihten kısa süre sonra kapatılmıştır. Kapanmadan önce de Şark-i Rus gazetesinin satılığa çıktığını ve A. M. Topçubaşı'nın da onunla ilgilendiğini buradan anlamış oluyoruz. Ancak İ. Gaspıralı ileride basın özgürlüğünün olacağını düşünerek yeni bir gazete çıkartabileceklerinden bahsetmiş ama bu teşebbüs ileriki dönemlerde gerçekleşmemiştir. Bunun yanında İ. Gaspıralı'nın insanların yeteneklerini keşfedip onları ilgili alanda hizmet etmeleri için hazırladığı anlaşılmaktadır. Bunun en iyi örneklerinden biri de mektupta görüldüğü gibi İsmail Lemanov'dur. Ayrica o dönemde İ. Gaspıralı kendisini çok yorgun hissediyor ve Tatarların bir kısım yanlış hareketlerinden de şikâyetçidir.

reisi görevini yürütmüştür. Haziran 1904 yılında istifa edip Bakû'dan ayrıldı. 1905 İhtilâli sırasında Sosyalist-İhtilâlci Partisi'nin üyesiydi. 1905 yılının Kasım ayında yayımladığı "Halk üzerindeki hâkimiyet kimin ellerinde olmalı" adlı broşür yüzünden bir yıllık hapis cezasına çarptırıldı ama bu ceza ağır hastalığı yüzünden ertelenmiş ve sonradan infaz edilmemiştir.

${ }^{12}$ Kaspiy gazetesi: 1881-1918 yılları arasında Bakû'da Rusça çıkan uzun ömürlü bir gazetedir. 1897 yılında gazeteyi Azerbaycanlı petrol zengini ve hayırsever Hacı Zeynelabidin Tağıyev satın aldıktan sonra gazetenin redaktörlüğünü Ali Merdan Topçubaşı yapmışıı. Bu gazete Rusça çıkmasına rağmen Rusya Müslümanları matbuatında çok önemli yeri olmuştur (Aşırlı, 2009: 44-46).

${ }^{13}$ Tercüman gazetesi: 1883-1918 yılları arasında Bahçesaray'da İsmail Gaspıralı tarafından yayımlanan edebî, siyasî ve ilmî gazetedir.

${ }^{14}$ Şark-i Rus gazetesi: 1903-1905 yılları arasında Mehemmedağa Şahtahtlı tarafindan Tiflis’te yayımlanmış edebî, siyasî gazetedir. İlkin haftada üç defa, sonraları günlük olarak ve toplam 392 sayı çıkmıştır. O dönemde Rusya Müslümanları arasında İsmail Gaspıralı'nın Bahçesaray'da çıkardığı Tercüman gazetesi dışında özel ve Türkçe çıkan başka bir gazete yoktu (Türkyılmaz, 2008: 108).

${ }^{15}$ İsmail Lemanov (Limanov) (1871-1942): Kırım Tatarı, âlim, şarkiyatçı, dilbilimci, eğitimci. İstanbul ve Kahire'de Şark dilleri, Kur'an, İslâm hukuku ve tarihi eğitimini görmüş. 1905 yılından sonra Petersburg şehrine taşınmış, Çarlık Rusya'nın Devlet Duması'ndaki Müslüman Fraksiyonu'nun kâtibi, A. M. Topçubaşı'nın Duma'daki milletvekilliği sırasında ve daha sonra fraksiyonun davetiyle maaş karşılığında fraksiyon için çalışırken bir süre fiilen A. M. Topçubaşı'nın özel kâtibi görevini yapmıştır. Bakû Türkoloji Kongresi’nde (1926) bildiri sunmuş. 1921-1934 yılları arasında Kırım Üniversitesi'nin Şarkiyat Fakültesinde çalışmış. Petersburg'a gittikten Şarkiyat Enstitüsünün elyazmaları bölümünde çalışmış ve 1938 yılında "Pantürkizm hareketinin ideologlarından biri ve üç ülkenin ajanı" suçlamasıyla tutuklanmıştır. İş arkadaşlarının “elyazmaları bölümünün en iyi uzmanı” olduğunu söylemeleriyle 1939 yılında serbest bırakılmış ve II. Dünya Savaşı sırasında Petersburg'un Almanlar tarafından ablukaya alındığı yıllarda vefat etmiştir. 


\section{Belge 2: İsmail Gaspıralı’nın Ali Merdan Topçubaşı’na yazdığı 28 İyün [11 Temmuz] 1906 tarihli} mektup ve tercümesi:

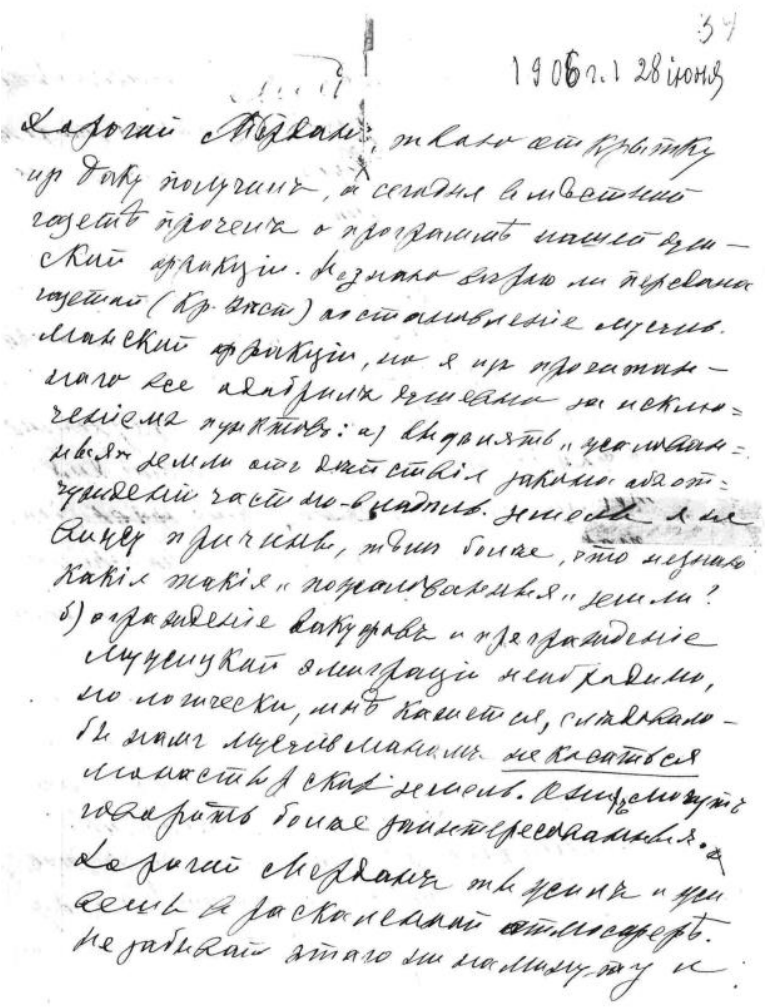

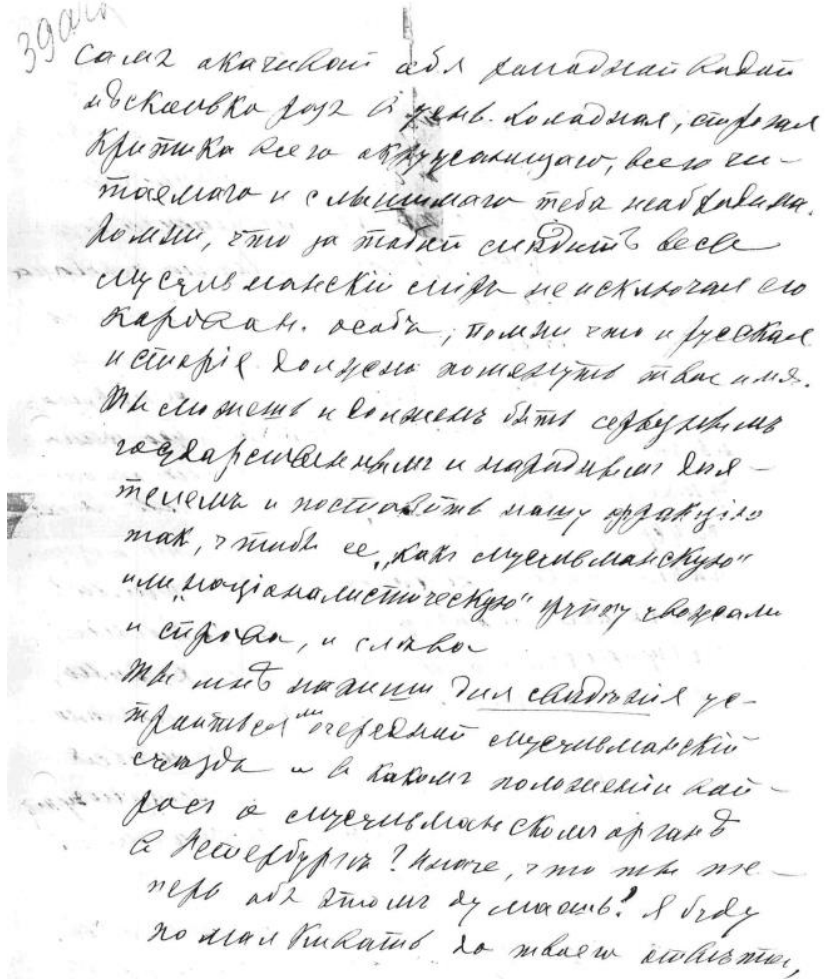

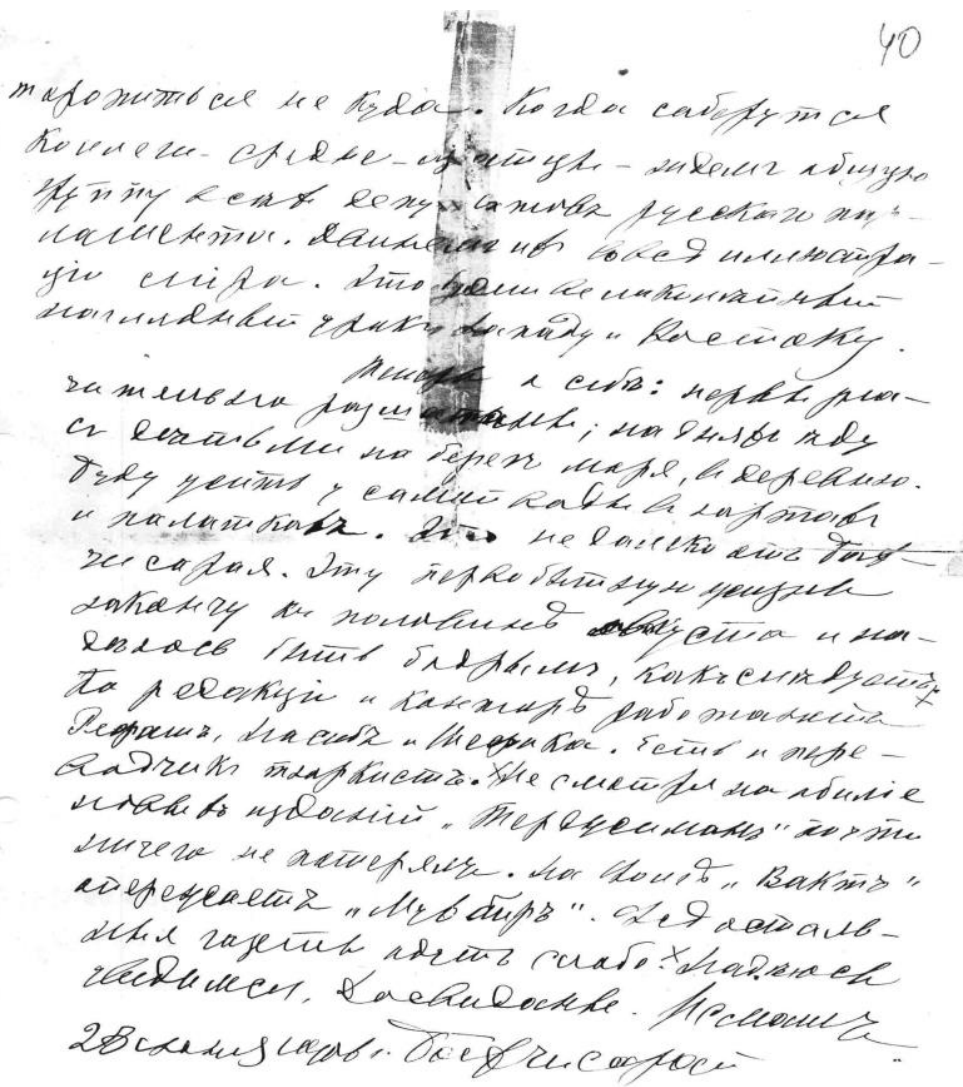


Sevgili Merdan, Bakû'dan gönderdiğin kartpostall aldım. Bugün de yerel gazetede Duma'daki bizim fraksiyonun" programını okudum. ("Kr[ımskiy] Vest[nik]",17) gazetesinin Müslüman fraksiyonun oluşumu hakkında doğru bilgi aktarıp aktarmadığını bilmiyorum, ama şu maddeler dışında okuduklarımın hepsini içtenlikle tasvip ettim: a) Yürürlükte olan özel mülk[iyetli] toprakları kamulaştırma kanuna dayanarak "ihsan edilen" toprakları tahsis etmek için bir sebep görmüyorum. Hem de bilmiyorum, hangi "ihsan edilen" topraklardan bahsediliyor? b) Vakıfların korunması ve mujik göçünün ${ }^{18}$ önünün kesilmesi gereklidir ama bence, mantıken, Müslümanların "manastır” topraklarına dokunmaması gerekiyor. Onlar hakkında daha ilgili olanlar konuşabilir.

Sevgili Merdan, sen gergin bir muhitte yaşıyordun ve yaşıyorsun. Bunu bir dakikalı̆̆ına bile unutma ve günde birkaç kez soğuk su dökün. Çevredekilerin, okunan ve duyulanların soğuk, sert eleştirisi sana gereklidir. Unutma, bütün İslâm âlemi ve onun taç giydiril[miş] şahsiyetleri de dâhil olmak üzere seni izliyor ve ismini Rus tarihi de [iyi bir şekilde] anmalıdır. Sen böyle ciddi devlet ve halk eylemcisi olabilirsin ve olmalısın ve bizim fraksiyonu "İslâmî" ya da "Milliyetçi" grup olarak hem săgdan hem de soldan saygl göreceği yere getirmelisin.

Bana, bilgi için bir sonraki Müslüman kongresinin düzenlenip düzenlenmeyeceğini ve Petersburg'daki Müslüman teşkilatı meselesinin durumu hakkında yaz. Başka deyişle şimdi bu konuda sen ne düşünüyorsun? Cevabını alana kadar sesimi çıkarmayacağım, zaten acelesi de yok. Orta Asyalı çalışma arkadaşları geldiklerinde Rus parlamentosundaki bütün milletvekillerinin genel grubunun toplanmasını bekliyoruz. Onların resimlerini dünyaya sunarız. Bu Batı ve Doğu için mükemmel bir görsel ders olacak.

Biraz da kendimden söz edeyim: Sinirlerim epeyce bozuk; bu günlerde çocuklarla birlikte deniz kıyısına, köye gidiyorum. Suyun kenarında kıl çadırlarında ve çadırlarda yaşayacağım. Orası Bahçesaray'a yakındır. Bu ilkel hayatı Ăgustos'un yarısına doğru bitirip gerektiği gibi dinleneceğimi umuyorum. Gazete idarehanesinde ve yazlhanesinde Rlfat ${ }^{19}$, Nesip ${ }^{20}$ ve Şefika ${ }^{21}$ çalışlyorlar. "Türkist",

${ }^{16}$ Burada Rusya İmparatorluğu'nun Devlet Duması'nda İyün [Haziran] 1906 tarihinde 22 milletvekilinden oluşan ve bunlardan 18'nin aynı zamanda Kadet Partisi'ne giren Müslüman Fraksiyonu'ndan söz edilmektedir. Fraksiyonun kurucusu ve lideri A. M. Topçubaşı'dır.

${ }^{17}$ Krımskiy Vestnik Gazetesi: 1888-1918 yılları arasında Sivastopol'de yayımlanmış gazetedir. Burada, Krımskiy Vestnik gazetesinde çıkan bir kısa yazıdan söz edilmektedir. Bu kısa yazıda, Müslüman Fraksiyonu'nun Duma'da görüştüğü toprak reformunun şu temel hükümlerinden bahsedilmiştir: "1-Kullanılan toprağın yüz ölçümü kişisel emek veya hayvancılıkla uğraşanlar için artırılmalıdır. 2- Rusya'da 1917 yılına kadar köylüye verilen toprak parçasının artırılması hazinenin payı, bakanlık ve manastır sayısına göre yapılıyor. Ayrıca özel malikânelerin/yurtlukların kamulaştırılmasıyla da yapılıyor. Ancak bu durumlarda topraklar adil bir ücret karş1lığında mülksüzleştirilir. Son kategorideki topraklar için istisna vardır: Mükâfat olarak verilen özel topraklar kamulaştırılamaz. 3-Vakıf arazileri kamulaştırılmamalı. 4- Bölgesel toprak fonunun oluşma ilkeleri. 5-Toprak kullanım düzeni mahallî yönetim tarafından düzenlenir. 6- Tehcir durduruluyor."

${ }^{18}$ Burada Rus hükûmetinin ele geçirdikleri topraklara yerleştirdikleri “mujik”ler (Rus, Ukrayna Moldovya köylüleri) kastedilmektedir. İsmail Gaspıralı ve Rusya Müslümanlarının diğer ileri gelen aydınları özellikle Türkistan'daki en iyi topraklara yapılan bu göçlerin durdurulması ve gasp edilen toprakların geri verilmesi gerektiğini savunmuşlardır.

${ }^{19}$ Rıfat Gaspıralı (1884-1925): İ. Gaspıralı'nın oğlu ve basın-yayın işlerindeki aktif yardımcısıdır. 1894-1904 yılları arasında Simferopol'deki erkek gimnaziyada okumuş. Sonra Kazan Üniversitesi Hukuk Fakültesine girmiş ve oradan da Harkov Üniversitesi'ne geçiş yapmıştır. 1909 yılından itibaren Tercüman gazetesinde çalışmaya başlamış ve babası İsmail Gaspıralı'nın vefatından sonra da gazetenin redaktörlüğünü yapmıştır. 1921 yılında açılan "İsmail Gaspıralı Ev Müzesi”nin müdürlüğünü yapmış, Bahçesaray’daki İ. Gaspıralı adındaki Kütüphane ve Han Sarayı Müzesi müdürü görevlerini de yürütmüştür.

${ }^{20}$ Nesip Bey Yusufbeyli (1881-1920): Azerbaycanlı yazar, Şefika Gaspıralı'nın kocası; Umum Rusya Kurucu Meclisi'nin adayı (1917); Türk Federalistleri Partisi'nin kurucusu (1918), Azerbaycan Demokratik Cumhuriyeti'nin Halk Eğitim ve Din İşleri Bakanı (1918-1919), İç İşleri Bakanı (1919), Azerbaycan Cumhuriyeti’nin Bakanlar Kurulu Başkanı (1919-1920) olmuştur. Bolşevik ajanlar tarafından öldürülmüştür. Nesip Bey Yusufbeyli’nin çalışmaları hakkında daha fazla bilgi için bakınız: Yılmaz Özkaya, Nesip Bey Yusufbeyli'nin Tercüman'daki Yazlları Üzerine Bir Değerlendirme, Yeni Türk Edebiyatı Dergisi, Say1: 9, Nisan 2014.

${ }^{21}$ Şefika Gaspıralı (Yusufbeyli) (1886-1975): İsmail Gaspıralı'nın kızı, gazeteci, Tercüman gazete idarehanesinin idarecisi olmuş, XX. yüzyılın başında Kırım Müslüman Kadın Hareketinin liderliğini ve 1905 yılında İsmail Gaspıralı'nın Kırım'da kurduğu ilk Müslüman kadın dergisi olan Âlem-i Nisvan'nın redaktörliğinü yapmıştır. 1906 yılında meşhur Azerbaycanlı toplum eylemcisi olan Nesip Bey Yusufbeyli ile evlenmiştir. Moskova'da 1917 y1lının 
[Türkolog] bir mütercim de var. Yeni yayınların bolluğuna rağmen, "Tercüman"22 neredeyse hiç bir şey kaybetmedi. Idil'de "Vakit"23 “Muhbir"'in ${ }^{24}$ önündedir. Diğer gazeteler ise zaylf kallyorlar. Umartm görüşürüz. Görüşmek üzere.

Ismail

1905 yılında Çarlık Rusya'da meydana gelen İlk Rus İhtilâli’nden ${ }^{25}$ sonra Rusya Müslümanları-Türkleri kısmî ve kısa süreliğine de olsa bir rahatlığa kavuşmuşlardır. Bu dönemde Rusya Müslümanları arasında yayın faaliyetleri artmıştır. En önemli gelişmelerinden biri de Rusya Müslümanlarının kongreler tertip ederek ileride yapılacakları hep birlikte ve planlı bir şekilde hareket etme kararı almaları olmuştur. İlk Rus İhtilâli’nin neticelerinden biri de Devlet Duması denilen Rus meclisinin açılması ve milletvekili seçimlerinin yapılması olmuştur. $\mathrm{Bu}$ meclise Rusya Müslümanlarından seçilen milletvekilleri olmuş ve mecliste İttifak-1 Müslimin olarak adlandırılan parti dahi kurulmuştur. İsmail Gaspıralı ile A. M. Topçubaşı birçok işte olduğu gibi bu meselelerde de ellerinden gelen her türlü desteği vermişlerdir. Hatta bu fraksiyonun kurucusu ve lideri A. M. Topçubaşı'dır.

Bu mektupta İ. Gaspıralı, gerektiği yerde yanlış bulduğu kısımları tespit ederek açıklamış, fraksiyonla ilgili çalışmaları yakından takip etmiştir. Bir önceki mektupta da görüldüğü gibi İ. Gaspıralı, Rusya Müslümanlarını destekleme adına elindeki en iyi imkânlardan biri olan basını kullanarak Devlet Duması'ndaki Rusya Müslümanlarının dış basında tanıtılıp söz edilmesi için resimlerinin basılacağından bahsetmiştir. Bunların yanında mektupta, İ. Gaspıralı'nın sinirlerinin bozulduğu ve deniz kenarında dinlenmeye gittiği anlaşılmaktadır. Onun yokluğunda Tercüman gazetesini kızı Şefika, oğlu Rıfat, damadı Nesip Bey ve diğer çalışanlar çıkarmaktadır. Böylece Tercüman'ın işleyişi ve o dönemde çıkan diğer gazetelerle olan ilişkiler hakkında birinci kaynaktan bilgi sahibi oluyoruz.

Mayıs ayında düzenlenen I. Umum Rusya Müslümanları Kongresi için Kırım'dan delege kadrosunun oluşturulmasında yardımcı olmuştur. 1917 yılının Kasım-Aralık aylarında düzenlenen Kırım-Tatar halkının I. Kurultayı'nın delegesidir. Kırım Halk Cumhuriyeti'nin dağıtılmasından sonra Bakû'ya gitmiş, kocasının ölümü üzerine de Türkiye'ye göç etmiştir.

${ }^{22}$ Tercüman gazetesi: 1883-1918 yılları arasında Bahçesaray'da İsmail Gaspıralı tarafından çıkartılan edebî, siyasî ve bilimsel gazetedir. 1888 yılında bu gazetenin Osmanlı Devleti topraklarına sokulması yasaklanmıştır. Çünkü gazetede yayımlanan materyaller, parlamentarizm fikrinin yayılmasından çekinen Osmanlı Devleti için problem oluşturmuş ve zaman zaman bu yasak kaldırılmıştır (Türkoğlu 2011: 83, 86).

${ }_{23}$ Vakit gazetesi: Orenburg'da Muhammed Şakir ve Muhammed Zakir Remiyev kardeşleri tarafindan ve başmuharrirliğini Fatih Kerimi'nin yaptı̆̆ı Vakit gazetesi, 1906-1913 yılları arasında haftada iki-üç defa ve İ. Gaspıralı'nın dil görüşüne bağlı Türkiye Türkçesine yakın bir dille çıkmıştır. 1913-1918 yılları arasında ise günlük yayımlanan içtimaî, siyasî ve edebî gazetedir (Remiyef, 1926: 12-14).

${ }^{24}$ Kazan Muhbiri gazetesi: 1905-1911 yılları arasında Kazan'da Seyid Geray Alkin tarafindan çıartılan gazetedir. Gazetenin ilk yıllarında Yusuf Akçura'nın hizmetleri ve yazıları da vardır (Remiyef, 1926: 6-7).

${ }^{25}$ İlk Rus İhtilâli ve Rusya Müslümanları hakkında daha fazla bilgi için şu kaynaklara bakınız: Салават Исхаков, Первая Русская Револючия И Мусульмане Российской Империи, Издательство “Социально-Политическая Мысль”, Москва, 2007; Salavat Midhatoviç İshakov, (Rusçadan Çeviren: Rıdvan Çitil), İlk Rus Ihtilâli ve Müslümanlar, Türk Dili ve Edebiyatı Araştırmaları Dergisi, Sayı / Number: 19 Temmuz-Aralık / July-December 2010, s. 313-325. 
Ayrıca buradan İ. Gaspıralı'nın işleri A. M. Topçubaşı ile karşılıklı danışarak yaptığı anlaşılmaktadır. Rusya Müslümanları arasındaki anlaşmazlıklara rağmen yapılan icraatların zorluğunu en iyi bilenlerden biri olan İ. Gaspıralı, A. M. Topçubaşı'ya yaptığı işlerde ve yapılan eleştirilere karşı desteğini esirgemeyerek onu “...unutma, bütün İslâm âlemi ve onun taç giydirilmiş şahsiyetleri de dâhil olmak üzere seni izliyor ve ismini Rus tarihi de [iyi bir şekilde] anmalıdır..." gibi çok güzel ve tarihe geçen ifade ile onurlandırarak teşvik etmiştir. Nitekim günümüzde yapılan araştırmalar neticesinde İ. Gaspıralı'nın bu tespitlerinde ne kadar haklı olduğu anlaşılmaktadır.

Bir de İ. Gaspıral1, Ali Merdan Bey'in çevresindeki ortamın problemli olduğunu bilmektedir. Dolayısıyla bu konuda kendisini uyarmaktadır. Ayrıca Ali Merdan Bey'in yapıcı eleştirilere de açık olması gerektiğini belirtmektedir. Ali Merdan Bey'in yaptığı iş ve çalıştığı ortamın zorluğunu ve ona karşı yapılan kimi haksız eleştirilerin olduğunu kayınvalidesi ve Azerbaycan Türklerinin önde gelen şahsiyetlerinden olan eğitimci ve Ekinçi gazetesini çıkaran Hasan Bey Melikzade Zerdabî’nin eşi ve eğitim almış ilk kadınlardan olan Hanife Melikova Zerdabî, Petersburg'a A. Merdan Bey’e gönderdiği 13 Aprel [26 Nisan] 1908 tarihli mektubunda şöyle ifade etmiştir: "Sizi burada görmeği ne kadar istediğimi bir bilseniz. Sizin işi düşündügümde yüreğim parçalanıyor, öfkeye kapıllyorum. Sonuçta bu bir devin işidir. Merdan, biraz da kendini düşünmek gerekiyor. Vallahi siz burada, eğer Bakûluları görmezden gelerek (en azından dışarıdan) Rus cemiyeti arasında yaşarsanız büyük değer kazanırsinız ve Müslümanların eğitimi için daha verimli çalışabilirsiniz. Bizim aydınlarımızın huzur içinde uyduklarını ya da herhangi bir pastanın yanında yer edinmeye çalıştıklarını biliyorum. Ahmed A ğayev İşad'ı bırakıp Mısır'a gitmek istiyor. O, tanınmamış kaldı̆̆ için sürekli sizi suçluyor. Psikopat! Diğer aydınlar hakkında ise yazacak bir şey yok, onlar ölüler." (İshakov 2012: 15). Görüldüğü gibi Hanife Melikova Zerdabî’nin bu mektubu hem İsmail Bey’i haklı çıkarıyor hem de Ali Merdan Bey'in ne kadar zor ortamda çalıştı̆ı̆ını gösteriyor. 
Belge 3: İsmail Gaspıralı’nın Ali Merdan Topçubaşı'na yazdığı 11 Sentyabr [24 Eylül] 1906 tarihli mektup ve tercümesi: ${ }^{26}$

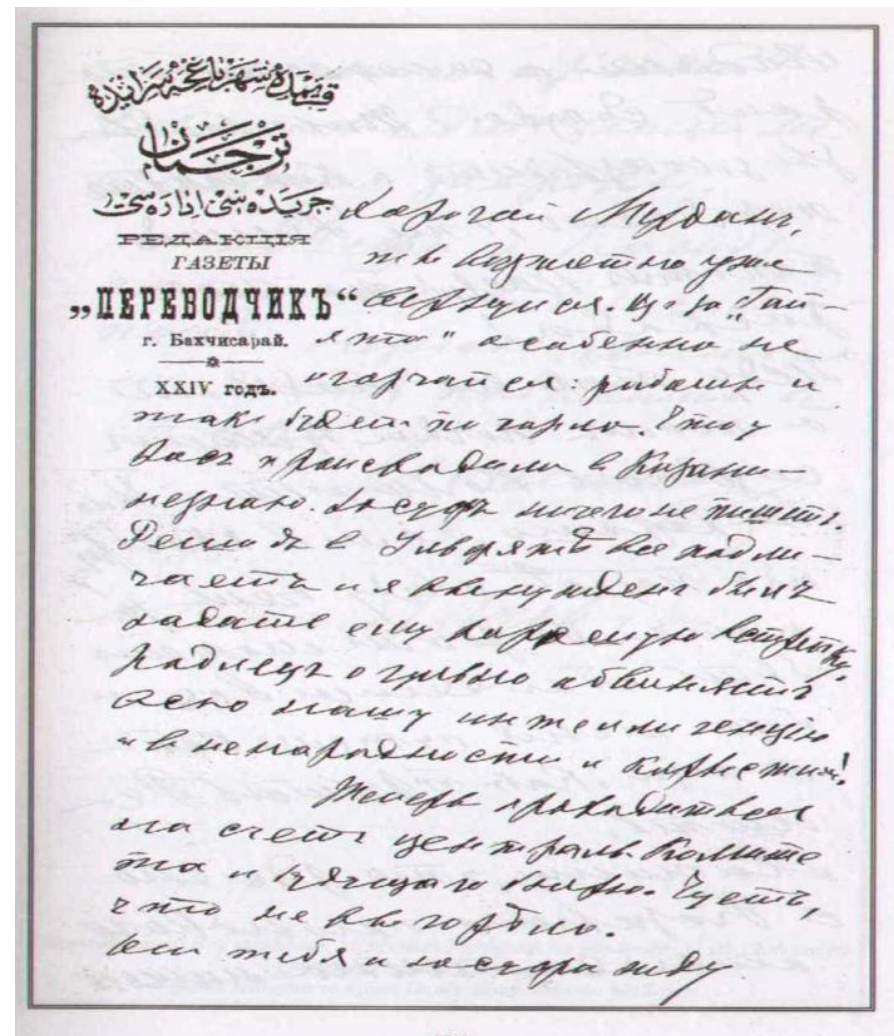

531

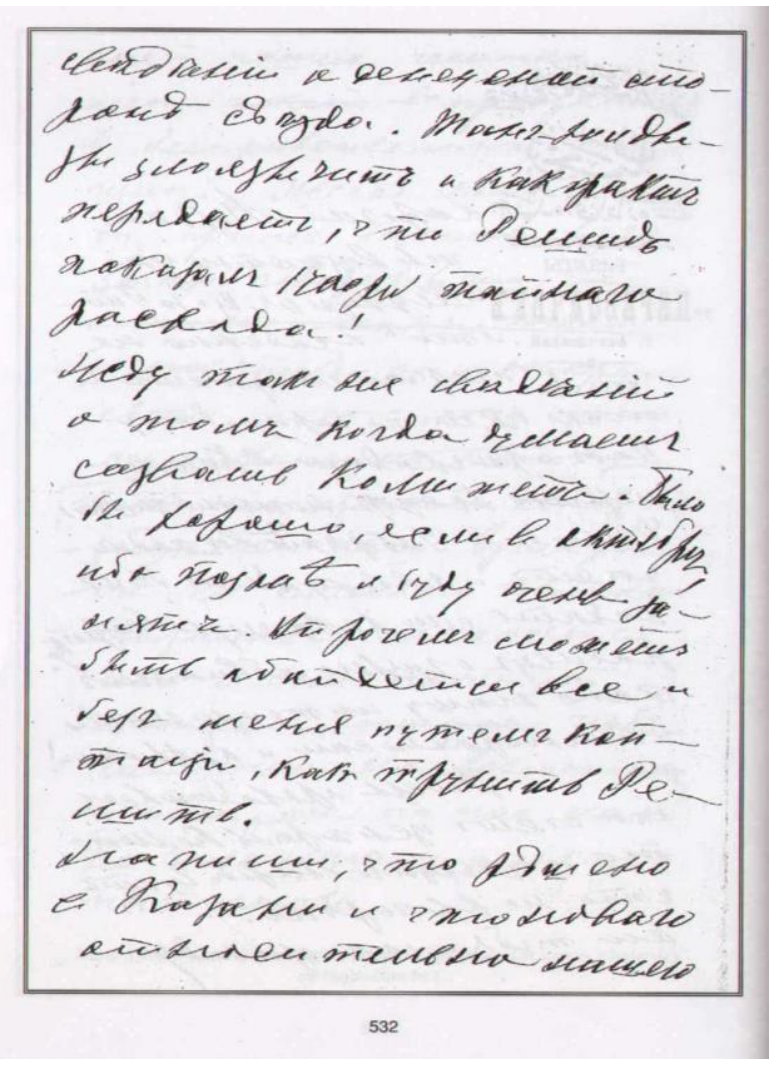

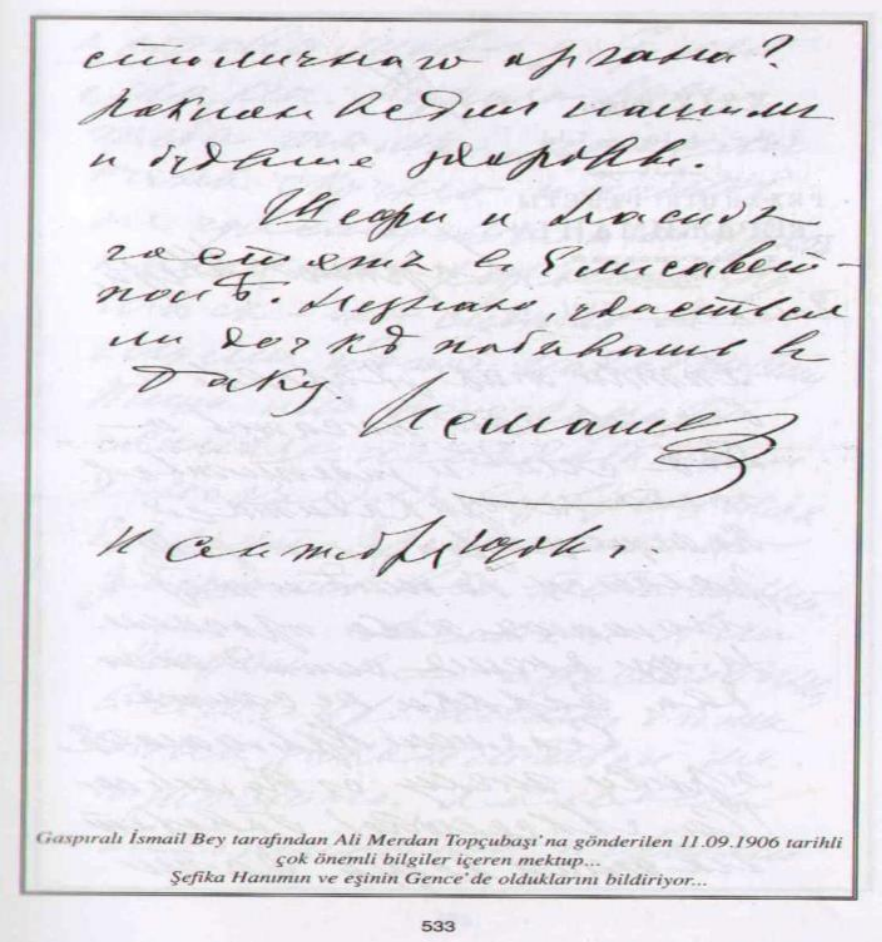

\footnotetext{
${ }^{26}$ Bu mektup şu kitaptan alınmıştır: Doç. Dr. Şengül Hablemitoğlu-Dr. Necip Hablemitoğlu, Şefika Gaspıralı ve
} Rusya'da Türk Kadın Hareketi (1893-1920), Ankara, 1998. s. 531-533. Faksimile. 
Sevgili Merdan, sen ihtimal dönmüşsündür. Özellikle "Hayat"27 için üzülme: Zaten işin başından aşkın olacak. Sizde, Kazan'da ne olduğunu bilmiyorum. Yusuff $f^{28}$ hiçbir şey yazmıyor. Reşid ${ }^{29}$ "Ülfet"te 30 alçakça davrantyor ve ben ona iyi bir ders vermek zorunda kaldım. Alçak, bütün aydın kesimimizi esassız bir şekilde namus[suz]lukla ve çıkar sağlamakla itham ediyor.

Şimdi Merkezî Komite'nin ${ }^{31}$ hesabından geçiniyor ve gelecekten korkuyor. Her şeyin bitmediğini seziyor.

Senden ve Yusuf'tan kongrenin maddî tarafi hakkında haber bekliyorum. "Tan Yuldız”, 32 , Reşid'in gizli geçimsizliğinin ilk belirtilerini gösterdiğine dair yerip çekiştiriyor ve gerçekmiş gibi haber veriyor!

Komiteyi ne zaman toplamayı düşündügüne dair de haber bekliyorum. Ĕ̌er Ekim ayında olursa iyi olurdu. Zira daha sonra çok meşgul olacă̆ım. Gene de belki her şey Reşid'in de alay ettiği gibi seçim yapılmadan kurula dâhil etme yoluyla bensiz de olur.

Kazan'da ne karar alındı̆̆ına dair yaz. Bizim başkent teşkilatıyla ilgili yeni bir şey var mı?

Bizimkilere selam ve sağlıcakla kalın. bilmiyorum

$S_{S} f_{i}^{33}$ ve Nesib, Yelisavetpol'de ${ }^{34}$ misafirdirler. Kızımın Bak̂̂'ya gidip gidemeyeceğini

${ }^{27}$ Hayat gazetesi: 1905-1906 yılları arasında Bakû'da Zeynelabidin Tağıyev'in sahipliğinde yayımlanan gazetedir. Sorumlu müdürlüğünü A. M. Topçubaşı, başyazarlıklarını ise Ahmet Ağaoğlu ile Ali Bey Hüseyinzade yapmıştır (Akpınar, 1994: 93).

${ }^{28}$ Yusuf Akçura (Akçurin) (1876-1935): Tatar hukukçu, iktisatçı, sosyolog, felsefeci, tarihçi, gazeteci, I-III Rusya Müslümanları Kongrelerine (1905-1906) katılmıș, Rusya Müslümanları İttifakı'nın Merkezî Komite üyesidir, Kadet Partisi'nin Merkezî Komite üyesidir (1906). 1908 yılında Türkiye'ye giderek yayıncılık ve eğitimcilik faaliyetlerini yürütmüştür. 1918 yılının başında Jön Türkler tarafından Sovyet idareyle iletişim kurmak amacıyla Petrograd'a gönderilen temsili bürokratlar grubunun üyesidir. 1923 yılından itibaren TBMM milletvekili, Türkiye Cumhuriyeti'nin Cumhurbaşkanı Gazi Mustafa Kemal Atatürk'ün kültür ve siyaset danışmanı olmuştur.

${ }^{29}$ Abdürreşid İbrahim (1857-1944): Buharalı (Sibiryalı Tatar), Tobolsk Vilayeti'nde doğmuş, Kazan Vilayeti'ndeki medresede okumuş ve burada öğretmenlik yapmıştır. 1877 yılında İstanbul'a gelmiş ve buradan Mekke ve Medine'ye gitmiş ve orada 4 yıl boyunca İ́slâmî eğitim almıştır. 1880'li yılların ortasında Rusya'ya geri dönmüş. 1885 yılında kendi şehri olan Tara'da mollalık ve mahallî medresede öğretmenlik yapmıştır. 1892-1893 yılları arasında Orenburg İdare-i Ruhaniye (Orenburg Müftülügü)'nin üyesidir. Sonra Mısır, Cezayir, Türkiye ve diğer ülkelere seyahate çıkmıștır. 1895 yılında İstanbul'da "Coban Yıldızı" adlı kitabı yayımlanmıș ve sonra bu kitap Rusya'da yasadıșı yollarla yayılmıştır. Yazar bu kitapta Tatarların tarihini ele almıştır. Üstelik A. İbrahim burada, Rus idaresi altındaki Tatarların durumunu küçük düşürülmüş ve esaret altındadır diye nitelemiş ve dikkati, Müslümanların Rus hükûmetinin yardımıyla zorla Hıristiyanlaştırıldıklarını vurgulayarak, Müslüman halka karşı Çarlığın yürüttüğü Ruslaștırma siyasetini eleștirmiș, idaresi altında iki yıl çalıștığı Orenburg Müftülüğü'nün bașkanını eylemsizlikle, çıkarcılıkla ve onu Çarlığın ajanı olarak adlandırarak şiddetle eleştirmiştir. Bu kitap bütün Müslüman dünyasında ve Rusya Müslümanları arasında da çok güçlü sosyal yankı uyandırmıştır. A. İbrahim'in, İdare-i Ruhaniye sisteminin sefahatiyle ve özellikle Orenburg müftüsüyle olan savaşçı imajı, Müslüman halkın dinî-siyasî çalkantıların yoğunlaştığı ortamda Müslümanlara çok gerekli olmuştur. 1904-1907 yılları arasındaki Rusya İmparatorluğu'nun Müslüman hareketinin liderlerinden biridir.

30 Ülfet gazetesi: 1905-1907 yılları arasında A. İbrahim'in Petersburg'da çıkardığı siyasî ve ilmî gazetedir. Abdürreşid İbrahim, Aralık 1905 tarihinde üst çevrelerdeki tanıdıklarının bağlantısı sayesinde "Rusya Müslümanlarına Kardeş Sözü” gibi çarpıcı başlı̆̆ı olan siyasî ve bilimsel gazete olan Ülfet'i yayımlamıştır. Gazetenin bask1 sayısı 8000 nüshaya kadar çıkmıştır. Bu da o zamana göre az değildir. Gazete, şakirtlerin, yoksulların, sosyalist ve İslâm'a hizmet eden kadınların taraftarı olduğunu vurgulamıştır. Türk hükûmeti, Petersburg'daki elçisi vasıtasıyla Rusya Müslümanları tarafından 1905 yılından itibaren çıkartılan kimi gazeteleri ve özellikle de Ülfet gazetesinin kapatılması için girişimlerde bulunmuştur. Cevap olarak da bu tarz önlemin alınmasının Rusya kanunlarına göre aykırı olduğunu olmuştur. Bir süre sonra Rus iktidarı yine de Ülfet gazetesini basan matbaanın faaliyetini yasaklamıştır (Türkoğlu, 2011: 85).

${ }_{31}^{31}$ Burada Rusya Müslümanlarının İttifakı'nın Merkezî Komitesi kastedilmiştir.

32 Tan Yuldızı gazetesi: Fuat Toktarov'un 1906 yılının Mayıs-Kasım ayları arasında Kazan'da çıkardığı gazetedir (Remiyef, 1926: 16).

${ }^{33}$ Şefika Gaspıralı. İsmail Bey kızına “Şefi” olarak hitap etmiştir.

${ }^{34}$ Yelisavetpol': Azerbaycan'da Rus işgalinden sonra Gence şehrine verilen isimdir. 
20 Haziran 1905-15 Eylül 1906 yılları arasında yayımlanan Hayat gazetesinin nâşiri olan Ali Merdan Topçubaşı, I. Duma'ya milletvekili seçilmesiyle gazeteyle yeterince ilgilenememiştir (Aşırlı 2009: 61, 64). İsmail Gaspıralı da bu konuda Ali Merdan'ın üzülmemesi için moral vermiştir. Bilindiği gibi 1905 yılında Rusya Müslümanları, Nijniy Novgorod şehrinde düzenlenen Mekerce Panayırı'nda bir araya gelerek kongre düzenlemişler ve böylece Rusya Müslümanları için yeni bir dönem başlamıştır. Bir yandan Rusya Müslümanları mecliste temsil edilmiş ve Rus esareti altındaki soydaşların haklarını korumak ve iyileştirmek için önde gelenler çok büyük çabalar göstermişlerdir. Diğer yandan da A. M. Topçubaşı başta olmak üzere Rusya Müslümanlarının diğer temsilcileri, Petersburg'da kurmaya çalıştıkları Rusya Müslümanlarının İttifak Partisi’nin Merkezî Komite teşkilatı üzerinde İsmail Gaspıralı çok durduğu anlaşılmaktadır. Ayrıca İsmail Bey komitenin ne zaman toplanacağına dair Merdan Bey ile fikir alış verişinde bulunduğu görülmektedir. Bu mektuptan da bu işlerde Ali Merdan Bey’in öncülük ettiği, İ. Gaspıralı da ona her türlü desteği vermiş olduğu anlaşılmaktadır. O dönemde bu çalışmalar sırasında insanlar arasında çıkan anlaşmazlıklar da olmuştur. Bu mektupta da İsmail Gaspıralı ile Abdürreşid İbrahim arasında böyle bir anlaşmazlığın bulunduğunun delili niteliğindedir ve gazeteler üzerinden sürtüşmelerin olduğu da göze çarpmaktadır. 
Belge 4: İsmail Gaspıralı’nın Ali Merdan Topçubaşı’na yazdığı 24 Sentyabr [7 Ekim] 1906 tarihli mektup ve tercümesi:

$26-$ eylul19ob
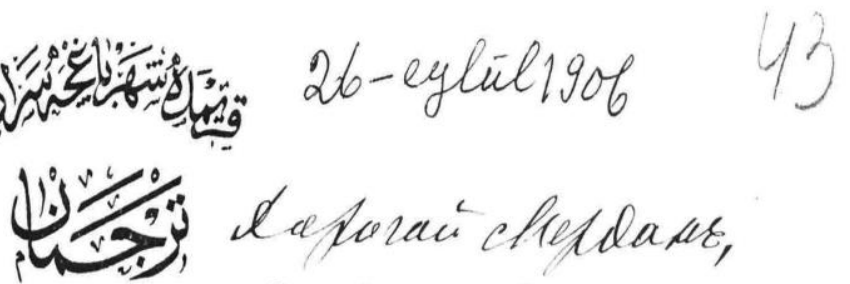

Lapraì chefdave,

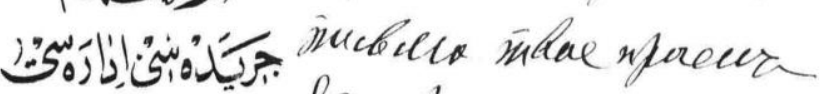

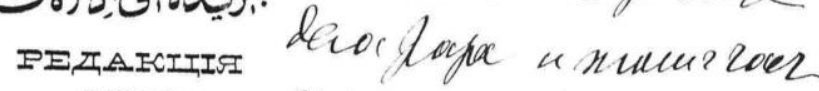

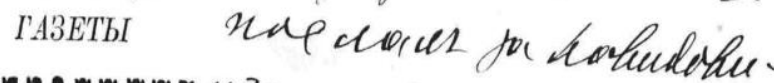

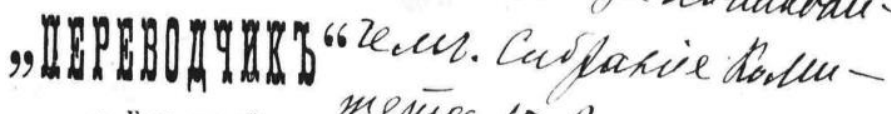

1. Бахчисарай. мемйer $45-20$ u ма 20-25

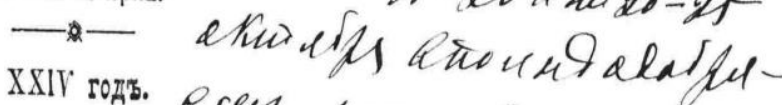

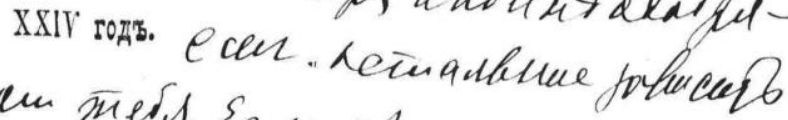

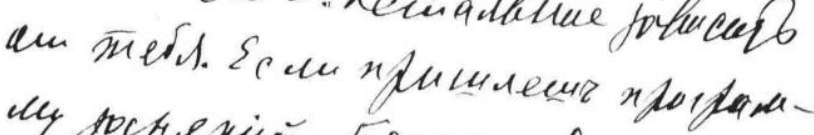

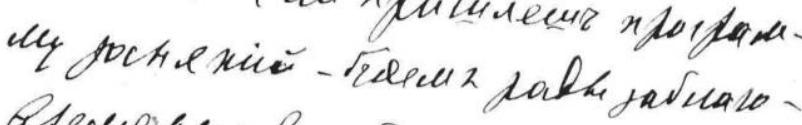
apsovesure bee ardy uamb. Ea, whe

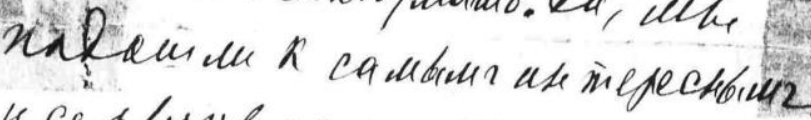

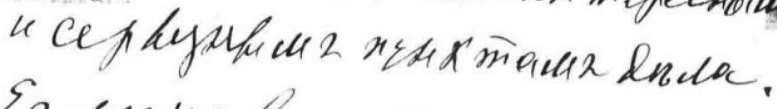
scumelee, niv resub curwal iden fracenma ain mala,

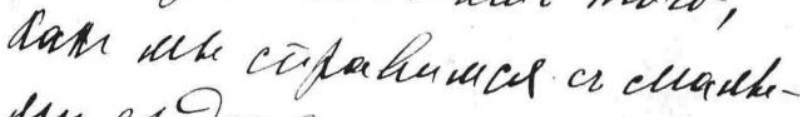

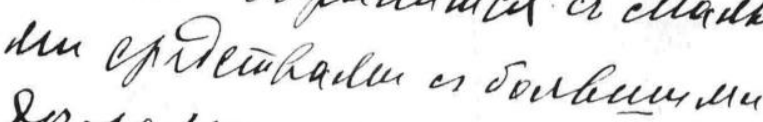
encordu.

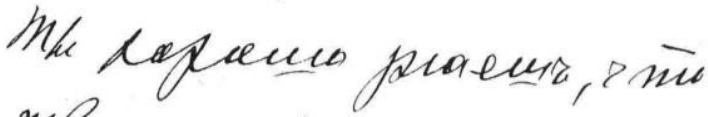

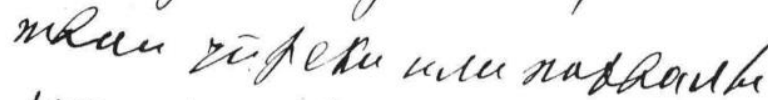

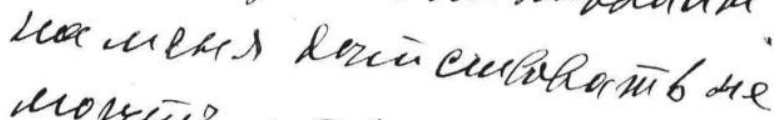

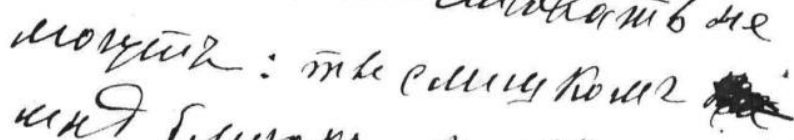

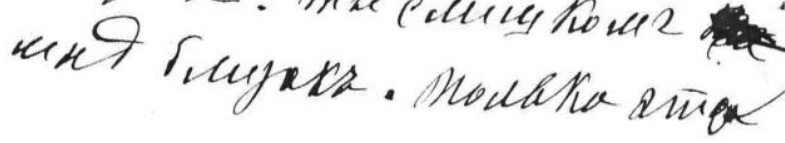

\section{Yhols}

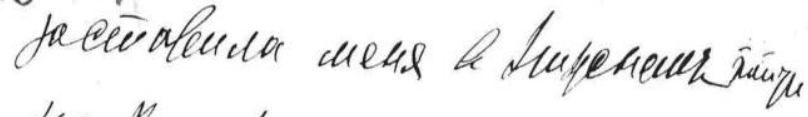

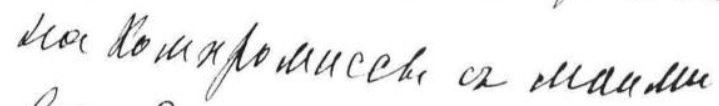

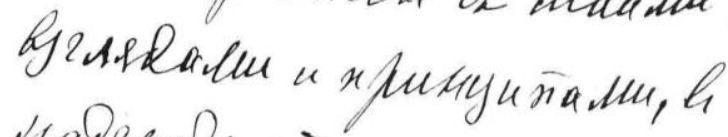

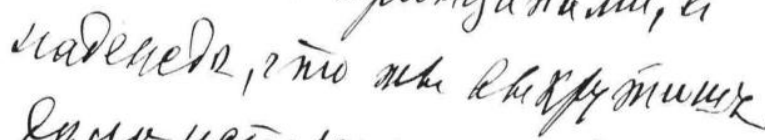

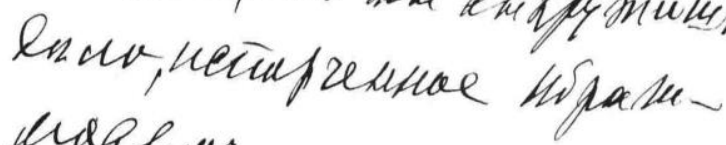
wakina.

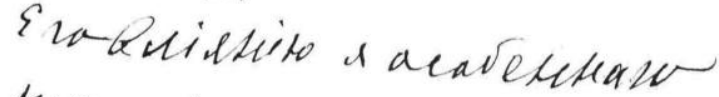

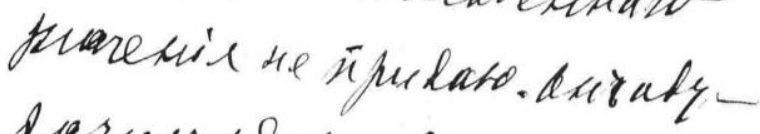

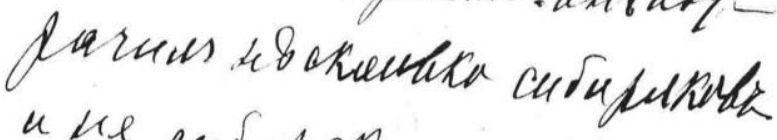

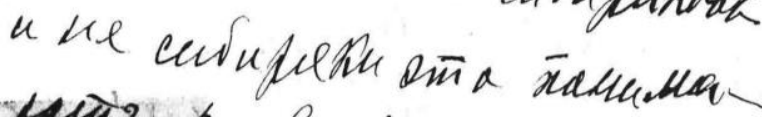

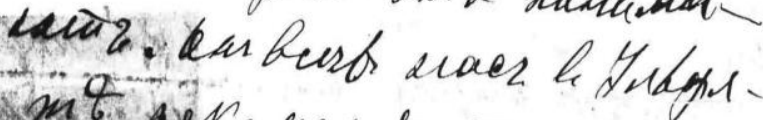

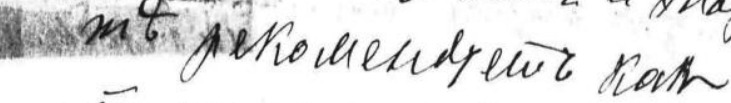
macidebonosyder a edy Ratier-

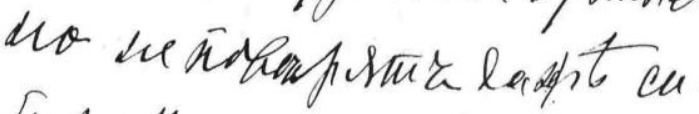

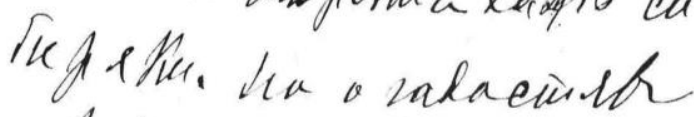
x pu ifandasin.

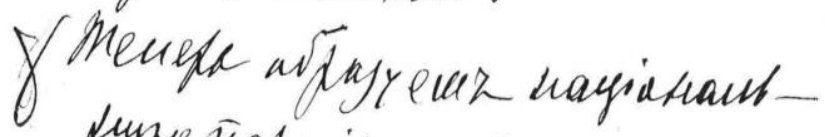

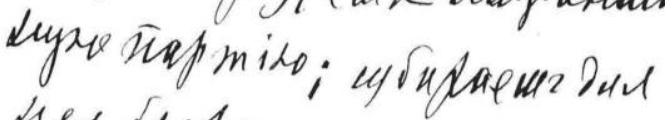
des raftar, nesablohiem

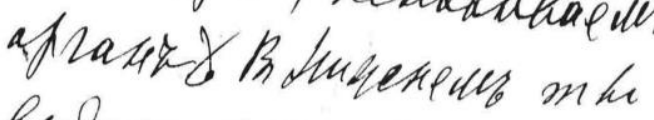
hubnur tratrae tel untur parare. 
kie nfulaems nadais paptwe. nino, resarbsacin, dodub no

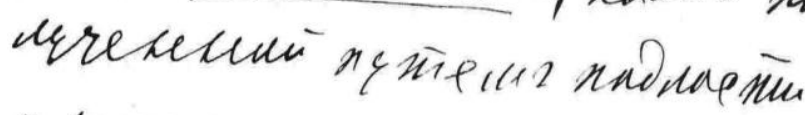

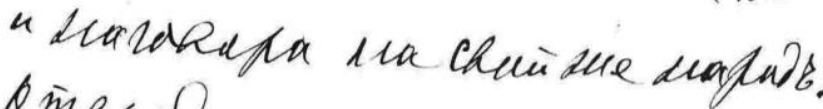
o m canba natssintlo, parkejunire.

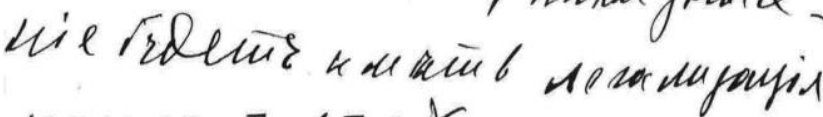

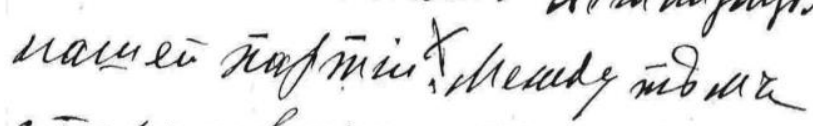
ciñana ufurcìtw, в ño caleùchas naphinis mpuracuetua on

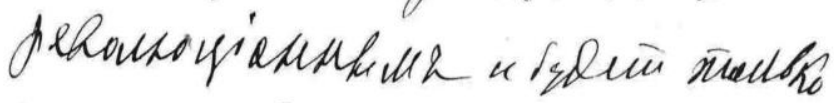

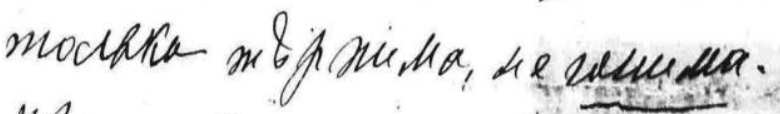
"1pu matro un a iu nametim xpolu.

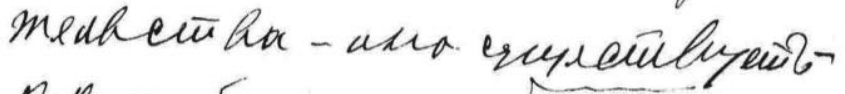

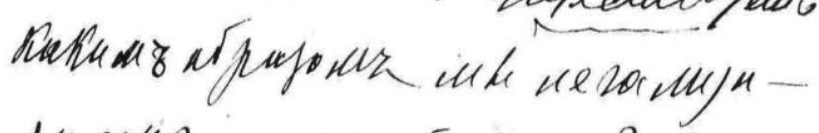
pyectir masey ñafmito? I Hellato,

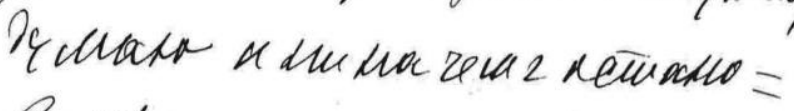
Gustrt ae de cury, a $\sqrt{y}$ desodu-

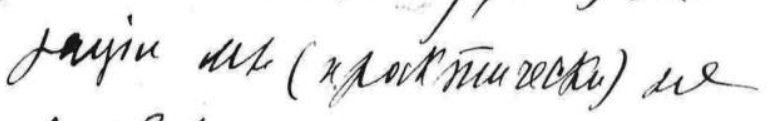

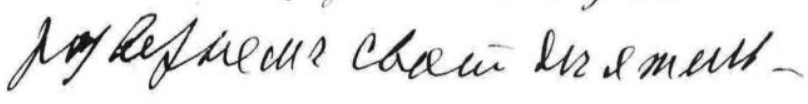

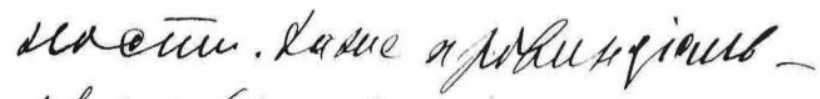

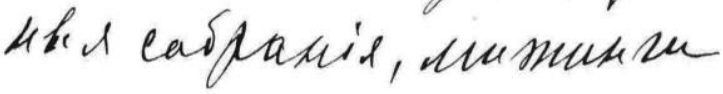
iтupariur he hoy mogetebidm

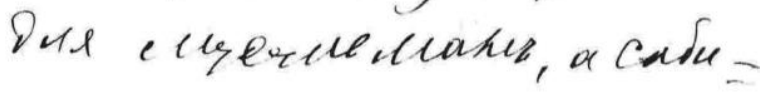

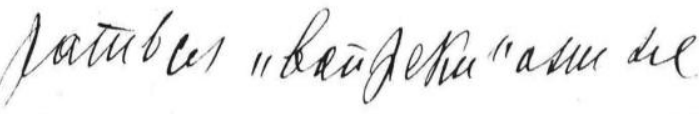

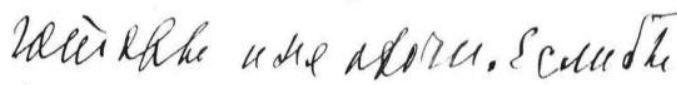
lnua cì̀ ana ua sñowey sño nuseralle, tho fasech, año

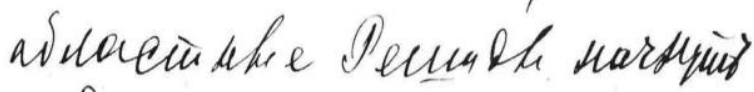

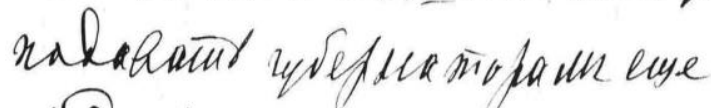
gount romesid, \& bas

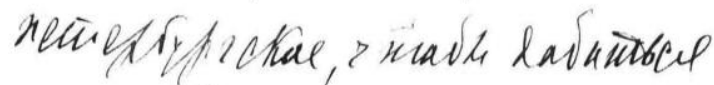

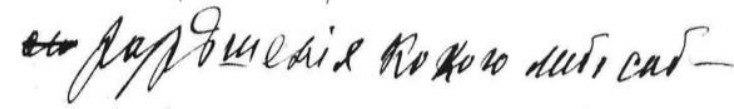
patiis, paen cesteñadadur.

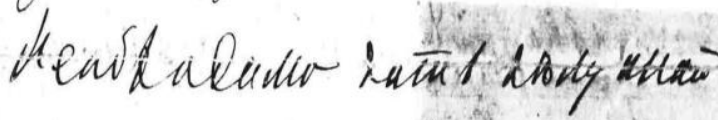

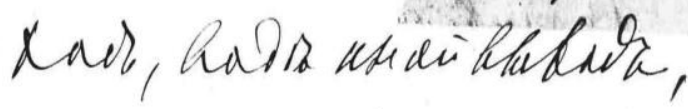

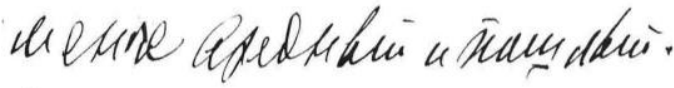
sain weit hasulued naser Hodn sumuetas yahara wo reprabo nepatr. Yentui who

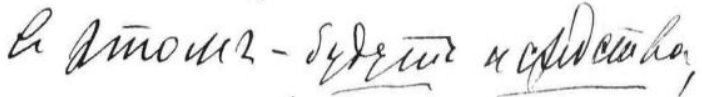
clento. X

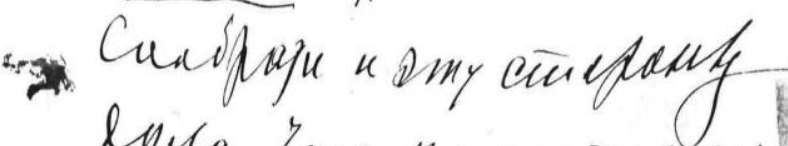
lnva. Ino tha easincel soje.

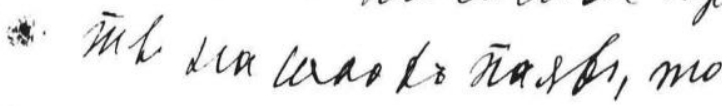

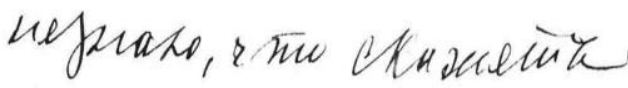



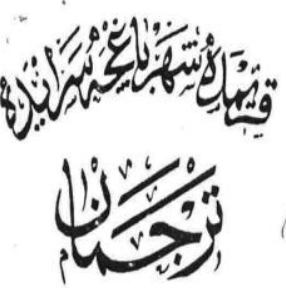

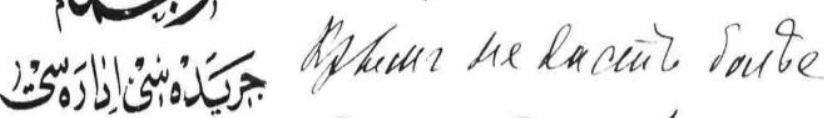
tapkay u he u 2a, to adsuazo ñas. A zo-ro
PEITAICIIIST

ГАЗЕТЫ

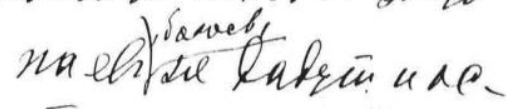

1. Бахчисарай. - mordateles nqdauteyiu; rosock; smestruld XXIY sод̈. suk'añwn cuyars uisatro aenduater.

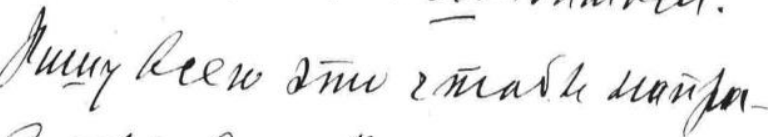
cutul mhase Musyrys, curradys

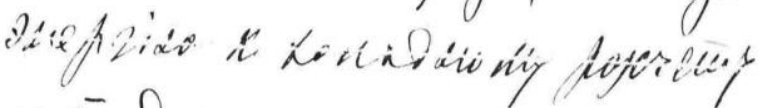
uñlereany, wrvaceredie

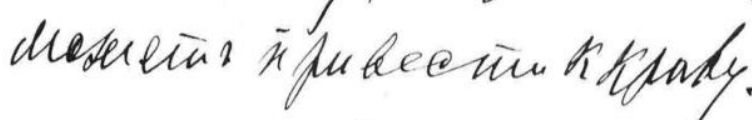
dial vartalbuirwie ne nowerkagif, yumyiativlar la enits coplatiis dawe we nemedsypi apratur "xar имesm hommotio.

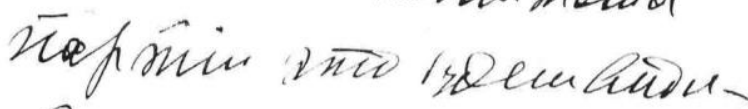
dit peje nuev. tho bue cardur
Whaty

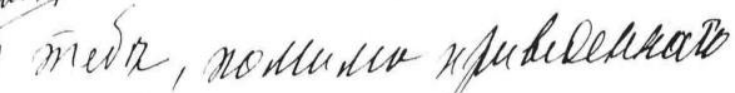
muser cleomutar.

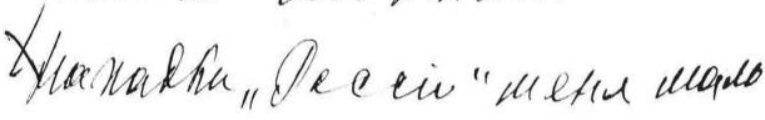

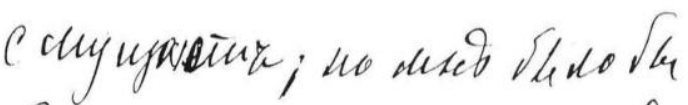

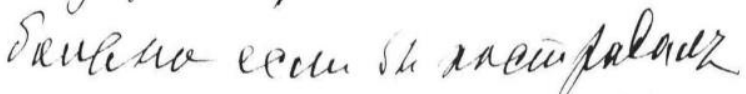

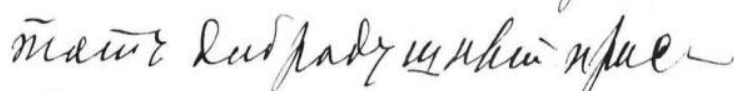

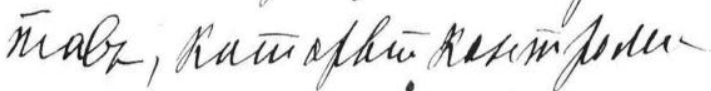

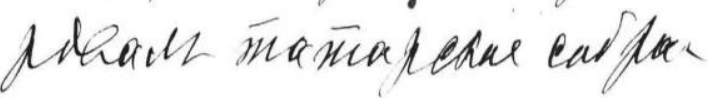
wie' tre meturtad un altwallo

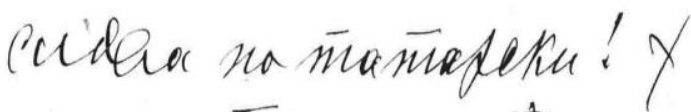
In juir cuterisus

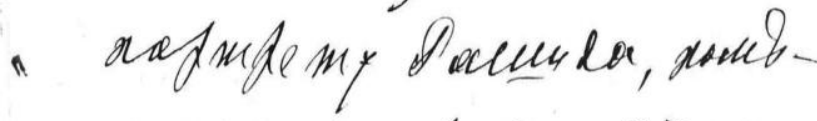

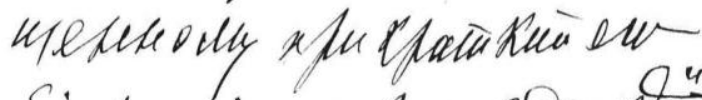

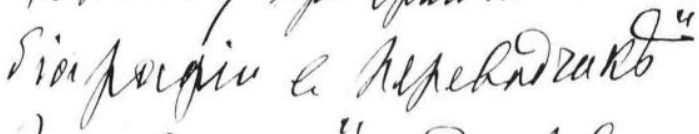

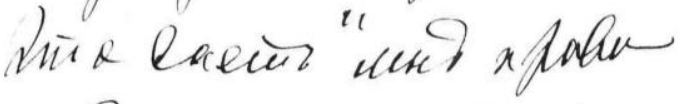
cucune uneapumb o eve

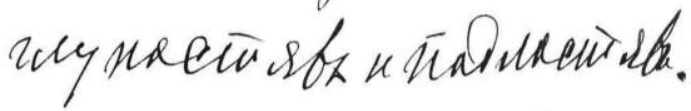
oveven. maxems

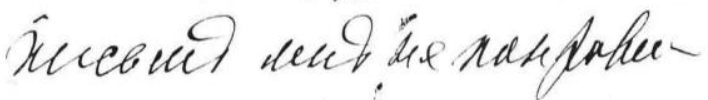
waeh atux cutho shediu nos be eturiemesiu lyaphr 
Scula 2.3 Sas la miraspr Pe undy-mo n cüasevo; atar

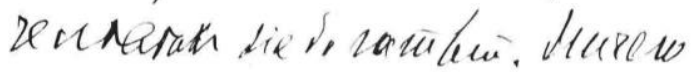

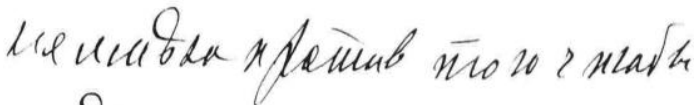

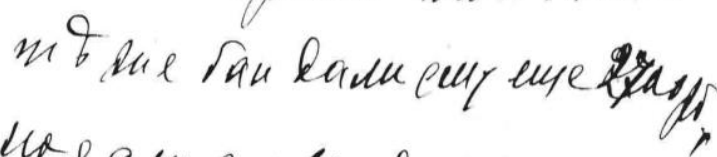
tre pun kesefm dathes so Crapk, na enfadies me

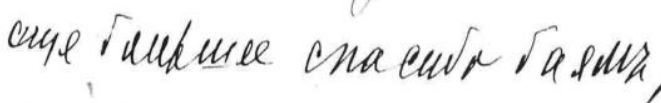

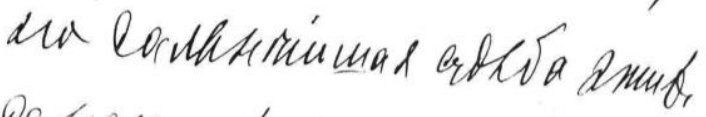

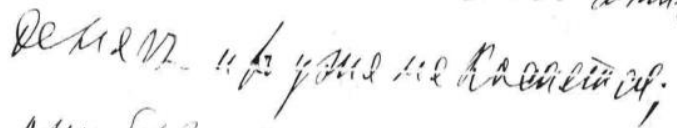

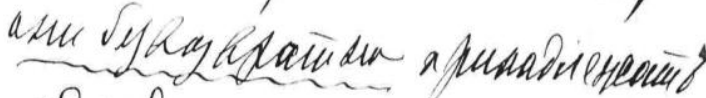

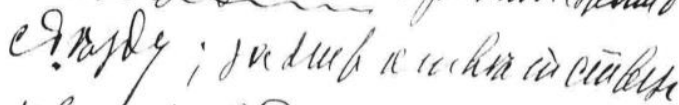
the whe het.

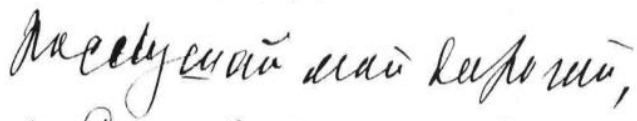

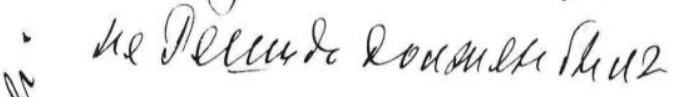
nuañwing, a Cowouth ñetes

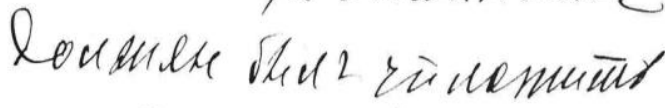

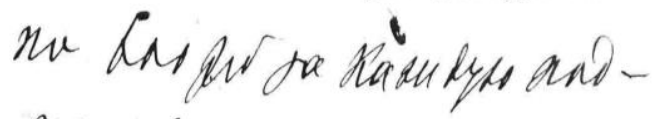
we th so dere cexcomadn tranesis.

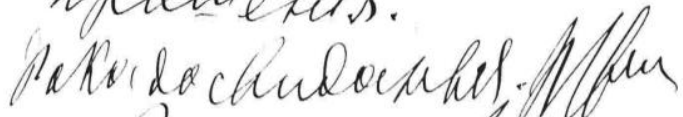
tochare

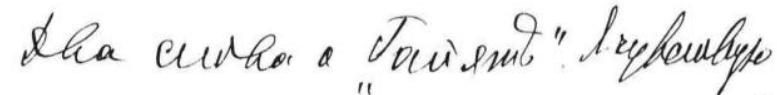

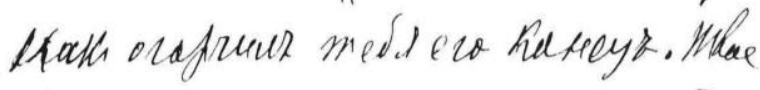

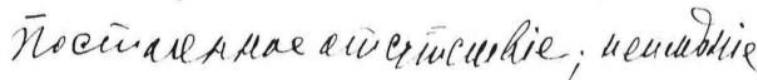

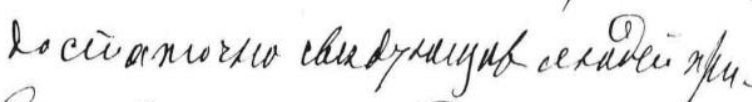

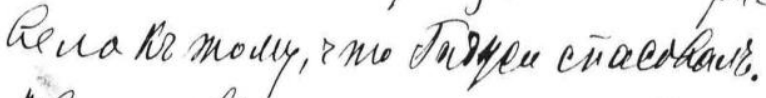

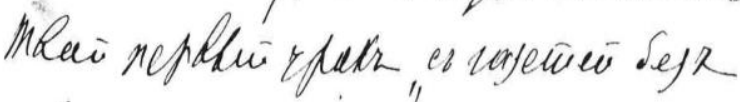

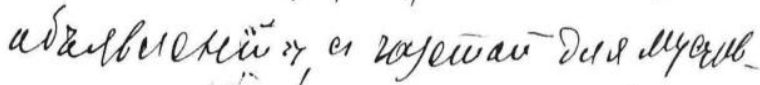

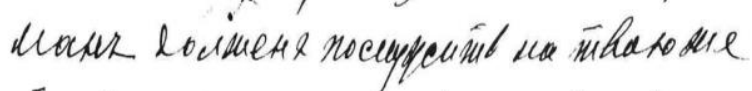

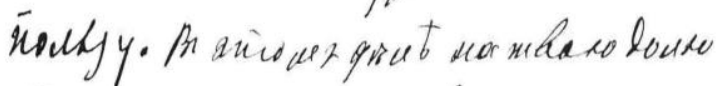
Huloreur maks me uthoma pas mi =

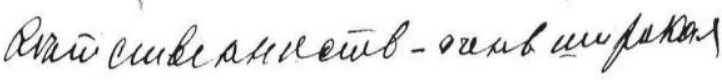

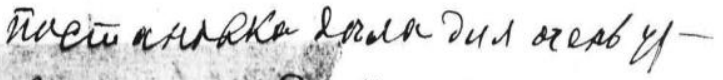

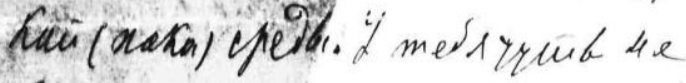

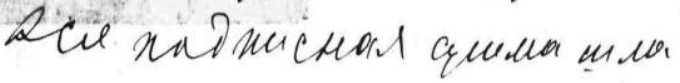

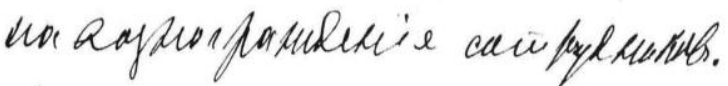
se nouma, ry unas, navaft? do cyearMocium nacrew ifth to wo rearete-

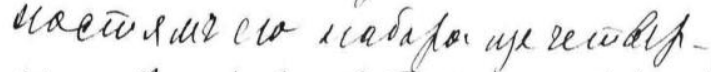
Main Ra ech N Tacisma u lifmala

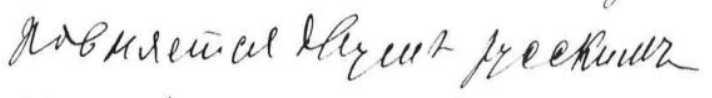

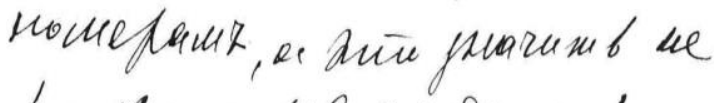
6 ald wometh a seincide.'

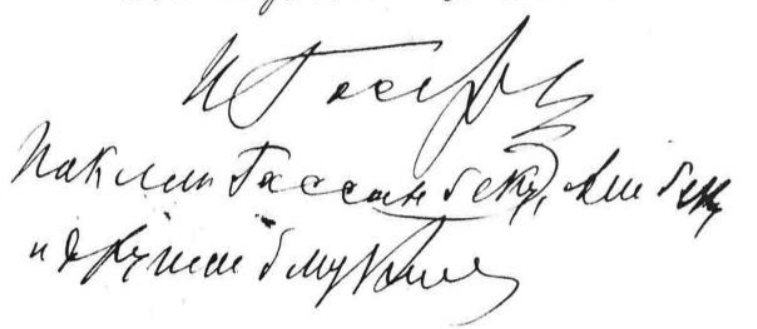


Sevgili Merdan, mektubunu okudum ve Zare'ye ${ }^{35}$ verip hemen Davidoviç' $i^{36}$ çă̆ırmak üzere gönderdim. Komitenin toplantısı için 15-20 veya 20-25 Oktyabr [28 Ekim-2 Kasım veya 2-7 Kasım] tarihlerini pekâlâ uygun buluyoruz, gerisi sana bağlı. Çalışmaların programını gönderirsen memnun oluruz. Her şeyi önceden ölçüp biçebiliriz. Evet, biz işin ilginç ve ciddi noktalarına yaklaştık. Hepsi değilse de pek çok şey bizim az imkânlarla büyük işlerin üstesinden gelmemize bă̆ll.

Iyi bildiğin gibi senin kınama veya övgülerin beni etkilemez: Sen bana çok yakınsın. Senin bu yakınlı̆̆ın sayesinde, [Abdürreşid] İbrahimov tarafından bozulan işi ${ }^{37}$ düzeltebileceğin umuduyla Nijniy'de ${ }^{38}$ kendi görüş ve prensiplerimle uzlaşmamı săgladı.

Onun etkisine ben çok önem vermiyorum. O birkaç Sibiryalıyı kandırdı ve Sibiryalı olmayanlar da bunun farkındadırlar. O, "Ülfet”te hepimizi gizli gâvur olarak tanıtıyor ve kuşkusuz ona Sibiryalılar bile inanmayacak. Çirkeflikler hakkında ise görüştüğümüzde.

Şimdi millî partiyi kuralım; onun için büroyu seçip teşkilatın temelini atalım. Kendi halkına alçaklık ve bühtanlık yapılarak elde edilmiş olsa bile halkın, izne ve kanuniliğe ne kadar büyük önem verdiğine Nijniy'de şahit oldun. Buradan da partimizin yasallaşmasının ne kadar önemli olduğu anlaşıllyor. Bu arada Kadet Partisi'nin ihtilâlci olarak nitelendirildiği belli oldu ve sadece tahammül edilebilir ama peşinden gidilmez olacak. Hükûmetin bu -var olan- tavrıyla bizim partiyi nasıl yasallaştıracağız? Ben düşünüyorum, düşünüyorum ve bir şeyde karar kllamıyorum; yasallaşma olmadan da biz (amelî olarak) kendi faaliyetlerimizi düzenleyemeyeceğiz. Müslümanların eyaletlerde toplantılar ve mitingler yapmaları bile imkânsı hâle gelecek, oysa onlar "her şeyi göze alarak" toplanmaya hazır ve istekli değiller. Durum böyle olsaydı bu problemin daha yarısı olurdu, ama korkarım diğer bölgelerin "Reşidleri", "biz çalıştık" uğruna valilere, herhangi bir toplantıya izin almak için Petersburg'a verilenden daha da kötü dilekçeler vermeye başlayacaklardır. Bu meseleye başka çare bulmak gerekiyor, ne de olsa başka çare daha az zararlı ve bayağıdır. İşte, bana bizim siyasî amacımız daha ilk merhalelerdeymiş gibi geliyor. Bu işi başardı̆̆ımızda imkân da güc de olacak.

Meselenin bu tarafinı da sen düşün. Pay esaslı gazeteye gelince, Kafkasya ve İdil'in ne diyeceğini bilmiyorum ama Kırım bir paydan fazla vermez. 30-40 payları ise korkarım diğer eyaletler de vermezler; bu konuda çok yanılmak isterdim.

Bunları senin coşkunu, genç enerjini soğukkanlı olmaya ve hesaplı hareket etmeye yönlendirmek için yazıyorum. Zira heyecan yıkıma yol açabilir.

Bizim Petersbur[g] teşkilatımızı kurma işindeki benim şahsî tesirim, tavsiyem ve girişimim yetersizdir, ama birlikte ve parti komitesi adına hareket edildiğinde bu olacaktır, görülüyor, makuldür. Söylediğin gerekçeden başka, aynı şeyi senin hakkında da söyleyebilirim.

“Rossiya”"nın ${ }^{39}$ saldırllarl beni fazla etkilemiyor; ama asıl Tatarca tek kelime anlamadan, Tatarların toplantısını ${ }^{40}$ denetleyen o iyi kalpli pristavı ${ }^{41}$ zarar görmesi beni çok etkilerdi!

Reşid'in [Abdürreşid Ibrahim] "Perevodçik”teki [Tercüman”daki] klsa biyografisiyle yayımlanan portresine kötü gülüyorsun. ${ }^{42}$ Bu bana, onun saçmalık ve alçaklıkları üzerine cesurca konuşma hakkını veriyor.

\footnotetext{
${ }^{35}$ Zöhre (Zare) Hanım: Tercüman gazetesi idarehanesinin çalışanı.

${ }^{36}$ Mustafa Davidoviç: Kırım Tatarı, XX. yüzyılın başında Bahçesaray belediye başkanı olmuş, XX. yüzyılın başında Rusya'daki Müslüman hareketinin etkin eylemcisidir.

${ }^{37}$ Burada 3. Rusya Müslümanları Kongresi'nin 1906 yılının Ağustos ayının ortasında Nijniy Novgorod'da yapılması için A. İbrahim tarafından düzenlenmiş ve İç İşleri Bakanı P. A. Stolıpin'e verilmiş olan izin dilekçesinden bahsedilmektedir.

${ }^{38}$ Yani Nijniy Novgorod, Rusya'da bir şehir. Burada Nijniy Novgorod'da 1906 yılının Ağustos ayında düzenlenen 3. Umumî Rusya Müslümanları Kongresi kastedilmektedir.

${ }^{39}$ Rossiya gazetesi: 1905-1914 yılları arasında çıkan Petersburg gazetesi ve hükûmetin yarı resmî yayın organıdır. Bu gazetede Rusya Müslümanları aleyhinde yazılar yayımlanmıştır.

40 Ağustos 1906 yılında Nijniy Novgorod'da düzenlenen 3. Umumî Rusya Müslümanları Kongresi’nden söz edilmektedir.

${ }^{41}$ Pristav (Пристав): Rusya'da 1917 yılına kadar mahallî polis şefi.
} 
Bana gönderdiğin mektupta sadece 1400 rubleyle ilgili "gizli olarak” ibaresini beğenmedim. Ĕger 2-3 bay [zengin] Reşid'e 1400 ruble verdiyse, verdikleri için să̆ olsunlar; o zengin adam değildir. Aynı bayların ona 2700 ruble daha vermelerine de karşı değilim; ama ĕger paralar "kongre ve toplantı" için verilmişse baylara daha da müteşekkirim; ancak verilen paranın akıbeti artık onları ilgilendirmiyor; paralar iade edilmez bir şekilde kongreye aittir; onlardan hepimiz sorumluyuz.

Azizim, dinle beni, verilen her bir dilekçenin imzası için ödenen 600 rubleyi Reşid değil de Stolıpin ${ }^{43}$ ödemeliydi.

Hoşça kal, görüşmek üzere.

Senin İsmail

"Hayat” hakkında bir çift söz. Gazetenin sonunun seni ne kadar müteessir ettiğini hissediyorum. Senin sürekli yokluğun; yeterince bilgili insanların eksikliği, Hacl'nın ${ }^{44}$ pes etmesine sebep oldu. Müslümanlar için "ilan almadan çıkan gazete” senin ilk tecrübendir. Bu tecrübe gelecekte senin yararına olacaktır. Bu işte senin payına (şimdilik) dar çevrede çok geniş iş yapma gibi bir sorumluluk düşüyor. Senin işinde abonelerden gelen paranın neredeyse tamamı çalışanların ücretlerine gidiyordu. Posta, kâğlt, dizgi ise?

Dilimizin bir şeyi kısa şekilde ifade etme kabiliyeti ve "Hayat” ile "Irşad”" ${ }^{45}$ dört sütunlu kusa dizgisinin özelliği sebebiyle çıkartılan bir sayı, Rusça çıkartılan gazetenin iki sayısına denk geliyor. Bu da haftada altı değil, on iki sayı çıkarmak anlamına geliyor.

I. Gaspr[inskiy]

Hasan Bey' $e^{46}$, Ali Bey' $e^{47}$ ve diğger yakınlara saygllar.

Önceki mektuplarda görüldüğü gibi bu mektupta da İsmail Gaspıralı Rus meclisinde Rusya Müslümanlarının İttifak Partisi'nin ve bunun Petersburg teşkilatının kurulması üzerinde çok durmuş ve her türlü desteği sağlamaya çalışmıştır. İsmail Gaspıralı ile Abdürreşid İbrahim arasındaki anlaşmazlığın da A. İbrahim’in Rusya Müslümanları Kongresi için aldığı izninin tarzından kaynaklandığı görülmektedir. Bilindiği gibi Birinci Rusya Müslümanları Kongresi’ne resmî izin alınamadığından, kongre Nijniy Novgorod'da Oka Nehri üzerinde "Gustav Struve” adlı gemide düzenlenmişti (Akpınar, 2013: 27). Bunu da gezintiye çıkacağı bahanesiyle yapmışlardır. İkinci Rusya Müslümanları Kongresi ilk başta Moskova’da düzenlenmeye planlanmıştı. Buna izin verilmeyince Petersburg'da yapılmasına karar verilmiş ve Petersburglu tüccar Maksudov kongre düzenleme başvurusunda bulunmuş ancak buna da izin verilmemiştir. Yine de kongreye gelen delegeler 13-23 Ocak tarihleri arasında otellerde ve şehir dışında

\footnotetext{
${ }^{42}$ İsmail Gaspıralı, Tercüman gazetesinin 1905-1906 yıllarının çeşitli sayılarında "Akgül Destesi” adlı ve 10 tefrika olarak devam eden bibliyografik yazıları yayımlamıştır. İsmail Gaspıralı, Tercüman gazetesinin 2 Avgust 1906 / 24 C. Ahir 1324 [15 Ağustos 1906] tarihli 85. sayısında "Akgül Destesi" yazı dizisinin dokuzuncu tefrikasında Abdürreşid İbrahim' in hayatı ve çalışmaları hakkında bibliyografik mahiyette bilgi vermiştir (Akpınar, 2010: 8, 2930). Burada İ. Gaspıralı'nın Abdürreşid İbrahim hakkında yazdığı bu dokuzuncu bibliyografik yazı kastedilmektedir.

${ }^{43}$ Pyotr Arkad'yeviç Stolıpin (1862-1911): Rus devlet adamı, İç İşleri Bakanı ve aynı zamanda Rusya İmparatorluğu Bakanlar Kurulu'nun başkanı (1906-1911) olmuştur.

${ }^{44}$ Hacı Zeynelabidin Tağıyev (1823-1924): Azerbaycan petrol madenleri sahibi ve zengini, bilim ve sanat koruyucusu ve Hayat gazetesinin yayımcisıdır.

${ }^{45}$ İşad gazetesi: 1905-1908 yılları arasında Bakû'da günlük, edebî, siyasî, ilmî, iktisadî ve içtimaî Türk dilinde çıkan Müslüman gazetesidir. Gazetenin müdürü ve imtiyaz Sahibi Ahmet Ağaoğlu'dur. Gazeteyi maddi açıdan Azerbaycan'ın petrol zenginlerinden İsa Bey Aşurbeyov desteklemiştir (Beşikçioğlu, 2008: I).

${ }^{46}$ Hasan Bey Melikzade Zerdabî (1837-1907): İktisatçı, yayımcı, Rusya Türklerinin ilk gazetesi olan Ekinçi’yi (1875-1877) çıkarmıştır. Bakû şehir Duma milletvekili olmuş. Ali Merdan Topçubaşı'nın kayınpederidir.

${ }^{47}$ Hüseyinzade Ali Bey (1864-1940): Azerbaycanlı fikir ve edebiyat adamı, gazeteci. Rusya ve Türkiye'de Türkçülük düşüncesini ortaya atan ilk önder şahsiyetlerden biridir.
}

\section{TFipe}


toplanarak Duma seçimleri ve İttifak Partisi'yle ilgili meseleleri görüşmüşler ve bir takım kararlar almışlar. Bu kararlardan biri de her yılın 15 Ağustos'unda kongrenin yapılması olmuştu (İshakov, 2007: 206-208; Devlet, 1999: 106-108).

Üçüncü Rusya Müslümanları Kongresi için resmi makamlardan izin alma işi Seyid Gerey Alkin'e verilmiştir. Ancak S. G. Alkin bunu başaramayınca izin alma işini Abdürreşid İbrahim, Alîm Mirza Maksudov, Musa Bigiyev, Lütfullah İshakov üzerlerine almışlar ve İç İşleri Bakanı P. A. Stolıpin'e kongre için başvurarak dilekçe vermişlerdir. Verilen dilekçedeki görüşlere başta İsmail Gaspıralı olmak üzere pek çok kimse de katılmamıştır (Devlet, 1999: 109; Akpınar, 2005: 341; Kurat, 1966: 138). Mektuptan da bu durum açıkça anlaşılmaktadır. Söz konusu dilekçe ve izin alma şekli ve gerekçeleri hakkında İsmail Gaspıralı da Tercüman gazetesinde bahsetmiş ve bu dilekçedeki maddeleri teker teker ele alarak eleştirmiştir (Akpınar, 2005: 341-346). Çünkü dilekçede şunlar yazmaktadır: "Biz Rusya otokrasisinin en sadık bendeleri olan Rusya Müslümanları, yaygın olan Panislamizm fikirlerinin ve halkın mukadderatını tehlikeye koyan sosyalizm, anarşizm gibi yıkıcı düşüncelerin geniş halk kitlelerine nüfuz etmesinden duyduğumuz endişe ve bu düşüncelerin İslâmiyet'in prensiplerine aykırı olduğunu göz önünde bulundurarak, bu gibi akımlara meşru bir şekilde mücadeleye karar verdik. Biz, Rusya Müslümanları, bu gibi, türlü dış memleketlerden gelen yeni fikirlerden azadeyiz. Biz, kendi Ak-Çarımıza ve onun tahtına, bizden önce ata ve dedelerimizin yaptıkları gibi sadakatle hizmetimizde devam edeceğiz. Bundan ötürü, sosyalizm, anarşizm ve Panislamizm gibi düşüncelerin yayılmış olması keyfiyeti karşısında Zat-1 devletlerinden şu meselelerin müzakeresi maksadıyla bir toplantı akdine izin ve müsaade vermenizi rica ediyoruz: 1- Basında İslâmiyet'e aykırı olan görüşlerle mücadele; 2- Molla, müftü ve şeyhülislamların halk tarafından seçilmesi ve din adamlarının mali durumunun ıslahı; 3 - Mektep ve medreselerin mollaların elinden alınarak, halkın idaresine verilmesi ve ıslah edilmesi; 4- Din adamlarının maddi durumlarının düzeltilmesi için yapılacak teberrular ve vakıflar meselesi (Kurat, 1966: 138-139; Devlet, 1999: 109).

Bir de bu mektuptan Rusya Müslümanlarının-Türklerinin ilerlemeleri işine gönül verenlerin Rus gazetelerinde yanlış ve aleyhlerinde yazıların yazıldığı da görülmekte ve İsmail Gaspıralı'nın Tercüman'ı ne denli etkin ve faydalı kullanarak bunlara karşılık verdiği anlaşılmaktadır. 1905-1914 yılları arasında Petersburg'da çıkan ve hükûmetin yarı resmî yayın organı olan Rossiya [Rusya] gazetesi Rusya Müslümanları aleyhinde yazılar yayımlamıştır. Bunlara İsmail Bey Tercüman gazetesi vasitasıyla cevap vermiştir. Örneğin Tercüman gazetesinin 20 Aprel 1907/20 R. Evvel 1325 tarihli 37. sayıdaki "Rusiya Gazetesine Cevap" adlı yazıda, Rossiya gazetesinin Tercüman'dan ötürü “Lisan-ı Türk şiveleri şu kadar ayrımıdır ki 
biri ile söyleyen halk diğeri ile mütekellim olanı anlayamıyor; bundan ötürü Müslüman şubesindeki vekiller öz arası Rusça söyleşiyorlar. Tercüman gazetesi bunu hoş görmeyip öpkelediği [sinirlendiği] gülünç bir hâldir.” dediği anlaşılmaktadır. İsmail Bey de Duma'daki Müslüman vekillerin Rusça konuştuklarına kızmayıp Fransızca ve İngilizce konuşsalar sevineceğini belirterek vekillerin ana dillerini iyi konuşamadıklarına üzüldügünü belirterek genel millî dil eğitiminin verilmesi gerektiğini savunmuştur. Ayrıca Rossiya gazetesinin zannettiği gibi Türkî şiveler birbirine uzak olmadıklarını ve herkesin iki ay gibi kısa sürede eğitim alarak genel Türk dilini öğrenebileceğini söylemiş ve Türk şivelerini birer başka lisan ve Türk taifelerini birer başka millet göstermenin ayrımcıların mesleği olduğunu belirtmiştir (Akpınar, 2008: 109-110).

Ayrıca Ali Merdan Bey'in pay esasına dayalı gazete çıkarma teklifini şimdilik İsmail Bey'in makul görmediği anlaşılmaktadır. Bu muhtemelen İttifak Partisi’nin yayın organı ve sözcüsü olarak çıkartılması düşünülen gazetedir. Hayat gazetesinin kapanmasına ${ }^{48}$ A. M. Topçubaşı'nın çok üzüldüğü için İsmail Bey ona moral vermiştir. Buradan da o dönemde ilan almadan Türkçe gazete çıkarmanın Rusça gazete çıkarmaya göre iki kat daha zor olduğu anlaşılmaktadır. Böylece bu mektuptan dönemin basınında çıkan gazeteler hakkında başka bilinmeyen ayrıntıları öğrenmiş oluyoruz.

\footnotetext{
${ }^{48}$ Bir de Hayat gazetesinin kapanma nedenlerinden birisi olarak Ahmet Ağaoğlu, Hüseyinzade Ali Bey’e yazdığ Fransızca mektubunda Hacı Zeynelabidin Tağıyev'i çok sert eleştirmiştir. Bilindiği gibi Hüseyinzade Ali Bey ve Ahmet Ağaoğlu ve Ali Merdan Topçubaşı, petrol zengini ve hayırsever Hacı Zeynelabidin Tağıyev'in maddi destekleriyle Hayat gazetesini çıkarmaya başlarlar. Sert bir mizaca sahip olan Ahmet Ağaoğlu, Hacı Zeynelabidin Bey'in Hayat gazetesine karışmasını pek istememiştir. Bu yüzden de Hayat gazetesinde yaklaşık bir yıl çalıştıktan sonra Ali Merdan Bey'in, Tağıyev'i gazeteye karıştırması sebebiyle ayrılmış ve Bakû'nun başka bir zengin yardımseveri İsa Aşurbeyli'nin maddi katkılarıyla İş̧ad gazetesini çıkarmıştır. Ağaoğlu'nun Hayat gazetesinden ayrılması ve Hüseyinzade Ali Bey'in Hacı Zeynelabidin Bey ile aralarının açılması bununla beraber Ali Merdan Bey'in ayrılmasıyla da Hüseyinzade'nin tek başına kalması gazetenin kapanmasına sebep olmuştur. Burada Hacı'nın pes etmesinden ziyade adı zikredilen şahısların aralarında anlaşmazlıklar olmuştur. Hatta Ahmet Ağaoğlu Hacı Zeynelabidin Bey için “bankacı zihniyetli kaba adam” tabirini kullanmıştır. (Özkaya, 2011: 24-25)
} 


\section{Belge 5: İsmail Gaspıralı’nın Ali Merdan Topçubaşı’na yazdığı 11 Aprel [24 Nisan] 1908 tarihli} mektup ve tercümesi: ${ }^{49}$

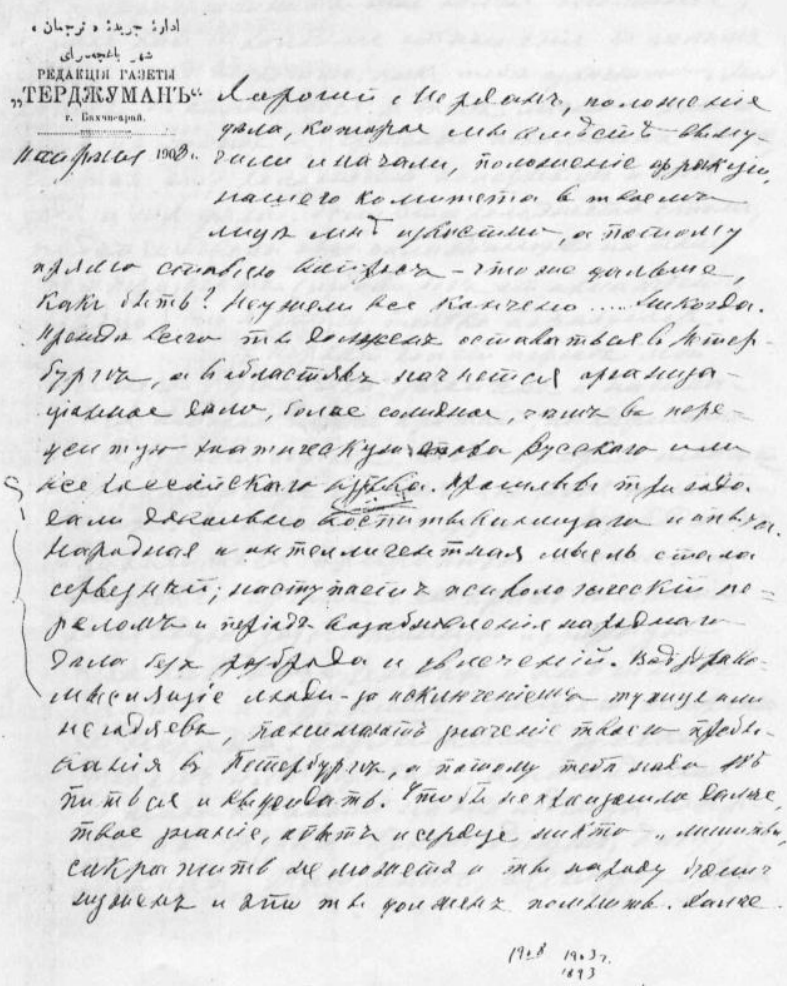

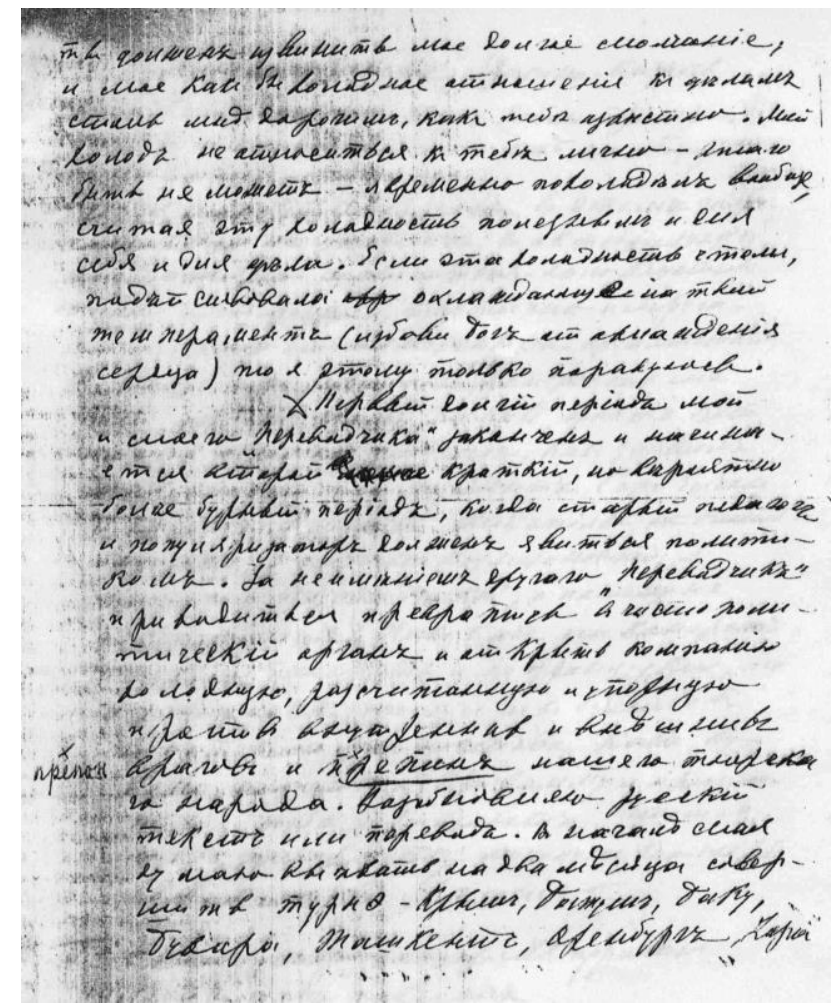

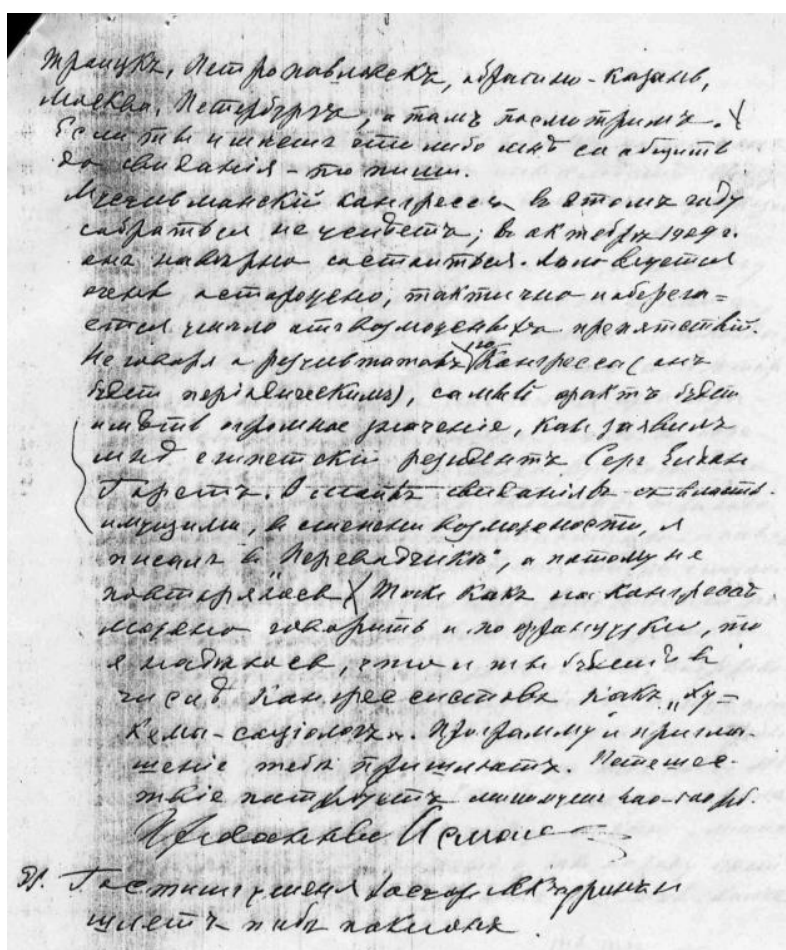

\footnotetext{
${ }^{49}$ Bu mektubu, Halil Açıkgöz Beyefendi, İ. Gaspıralı'nın Şefika Hanım'ın İstanbul'da oturan kızı Zöhre Gökgöl Hanımefendi'den temin etmiş ve Prof. Dr. Yavuz Akpınar Hoca'ya yayımlaması için vermiştir. Rusçadan tercümesini de Prof. Dr. Hacali Necefoğlu yapmıştır.
} 
Sevgili Merdan, birlikte eziyetini çektiğimiz ve başladı̆̆ımız işlerin durumu, fraksiyonun, senin şahsinda komitemizin vaziyeti bana malumdur ve bu yüzden doğrudan soruyorum: Bundan sonra ne olacak, ne yapmallyız? Acaba, her şey bitti mi? ... Asla! Her şeyden önce sen Petersburg'da kalmalısın. Eyaletlerde ise, geride kalan kaotik Rus veya umum Rusya kargaşa dönemindekinden daha ciddi teşkilatlanma işi başlayacaktır. Geçen üç yll h[alkl] yeterince eğiten deneyim kazandırdl. Halkın ve aydınların fikirleri ciddileşti. Psikolojik dönüm ve halk işinin düzenli ve heyecanll yenilenme dönemi başlıyor. Kalın kafalı ve alçaklar dışında sağduyulu düşünen insanlar, senin Petersburg'da bulunmanın önemini anllyorlar ve bu nedenle sen tutunmall ve hayatta kalmalisin. Bundan sonra ne olursa olsun, kimse bilgini, tecrübe ve kalbini senin "elinden alamaz”, azaltamaz, sen halka lazım olacaksin ve bunu unutmamalısın. Sonra, uzun süreli sessizliğimi ve senin de bildiğin gibi benim için çok değerli olan işlere karşı soğuk gibi görünen tutumumdan dolayı beni mazur görmelisin. Benim soğukluğum şahsen sana karşı değil ve olamaz da. Ben, bu soğukluğun hem kendime hem de işe faydalı olacă̆ını sanarak geçici olarak büsbütün soğudum. Eğer bu soğukluk senin heyecanını soğutmağa sebep olmuşsa (Allah kalbi soğumaktan korusun!) ben buna ancak sevinirim.

Benim ve "Perevodçik"imin [Tercüman"ımın] birinci uzun dönemi sona erdi ve ikinci, kısa, ama muhtemelen, yaşlı eğitimci ve maarifçiden bir siyasetçiye dönüşerek meydana çıkması gereken daha çalkantılı bir dönem başlıyor. Elimizde başka yayın olmadığından dolayı "Perevodçik" $i$ ["Tercüman"l] tamamen siyasî organa çevirmek, iç ve dış düşmanlara ve Türk halkımıza yönelik engellere karşı soğukkanlı, düşünülmüş azimli bir kampanya başlatmak gerekiyor. Rusça kısmı veya tercümeyi yeniden yayınlamağa başlıyorum. ${ }^{50}$ Mayısın başında iki aylık bir seyahate çıkmayı düşünüyorum: Kırım, Batum, Bakû, Buhara, Taşkent, Orenburg, Ufa, Troitsk, Petropavlovsk; dönüşte - Kazan, Moskova, Petersburg, gerisine orada bakarız. ${ }^{51}$ Ĕger görüşmemize kadar bana bir şeyler haber vermek istesen, yaz.

Müslüman Kongresi'nin toplanması bu seneye yetişmez ve muhtemelen Ekim 1909'da yapılır. ${ }^{52}$ Çalışmalar çok dikkatli, nazikçe ve muhtemel engellerden maharetle kaçınılarak yapılıyor. I. Kongrenin neticelerinden söz etmeden (o, süreli olacak), Misırlı temsilci Sir Eldon Gorst'un ${ }^{53}$ bana söylediği gibi, olayın kendisi büyük ehemmiyet kesp edecektir. İktidardakilerle görüşmelerimle ilgili imkân dâhilinde "Perevodçik"te ["Tercüman"da] yazdığım için tekrar etmiyorum. Kongrede Fransızca da konuşmak mümkün olacağından, delegeler arasında senin de bir "hükema-sosyolog” olarak katılacağını ümit ediyorum. Program ve davetnameyi sana gönderecekler. Seyahat için en azı 400-500 r[u]ble gerekecek.

Vefall Ismail

P. S. Hasan Akçura ${ }^{54}$ misafirimdir ve sana ihtiramını bildiriyor.

\footnotetext{
${ }^{50} \mathrm{Bu}$ ifadeye rağmen, belirtilen tarihten sonra Tercüman gazetesinde birkaç yazı hariç Rusça özel bölüm olmamıştır.

${ }^{51}$ Bilindiği gibi İsmail Gaspıralı 1908 yılında Buhara ve Semerkant’a kadar bir seyahate çıkmış ve yol boyunca gördüklerini Tercüman gazetesinin 47, 50, 57, 58, 60, 63, 64, 68 ve 78. sayılarında yayımlamıştır. Ancak İsmail Bey bu yazılarında, Bakû'da durmadan Krasnovodsk'a vapurla hareket etmiştir. Orada da durmayarak direk Taşkent'e giden trene binmiş ve yol boyunca Aşkabat, Merv ve Göktepe hakkında trenden gördüklerini kısa kısa anlatmıştır. Devamında da sadece Buhara ve Semerkant'a yaptığı ziyaretler hakkında bahsetmiş ve mektupta Ali Merdan Bey'e dediği diğer yerlere gidip gitmediği ve o yerler hakkında Tercüman'da hiç söz etmemiştir. Ayrıntılı bilgi için bakınız: İsmail Gaspıralı, Seçilmişs Eserleri: 3. Dil-Edebiyat-Seyahat Yazıları. Neşre Hazırlayan: Yavuz Akpınar, Ötüken Yayınevi, İstanbul, 2008. Sayfa 415-444. Bu mektubun yazıldığı tarih olan 11 Aprel 1908 ile Tercüman'da çıkan ve bu seyahatini anlatan "Yol Boyunda Gördüğüm, Sezdiğim" başlıklı yazının tarihi 27 İyün 1908/12 C. Ahir 1326'dır. Bu da İsmail Bey'in diğer yerlere de gitmiş olabileceği ama ihtiyattan dolayı bundan bahsetmemiş olabilir. Ya da hiç gitmemiş de olabilir. Şimdilik bunun ayrıntılarıyla ilgili herhangi bir bilgiye ulaşamadık.

${ }_{52}$ Burada İsmail Gaspıralı'nın toplamaya çalıştığı Dünya Müslümanları Kongresi kastedilmektedir. Bu amaçla İ. Gaspıralı 1907 yılının Ekim ayının ortalarında Kahire'ye gelmiş ve burada Rus hükûmeti ile cemiyetinin Rusya İmparatorluğu'ndaki Müslüman halkına karşı olan ilişkilerini ayrıntılı olarak yaptığı konuşmalarında nitelemiştir. Böyle kongre 1909 yılında düzenlenemedi ancak bu düşünce 1926 yılında Mekke'de gerçekleştirilmiştir.

${ }^{53}$ Sir Eldon F. Gorst (1861-1911): Hukukçu ve diplomat, Büyük Britanya'nın 1907-1911 yılları arasında Mısır Başkonsolosu olmuştur.

${ }^{54}$ Hasan Akçura (1866-1916): I. lonca dereceli Tatar tüccar, babadan gelen onurlu vatandaş, hayırsever, bilim ve sanat hamisidir.
} 
1905 y1lında meydana gelen İlk Rus İhtilâli’nden sonra Rusya Müslümanları kısmî de olsa bir rahatlığa kavuşabilmişlerdir. Ancak bu durum pek uzun sürmemiştir. P. A. Stolıpin'in İç İşleri Bakanı olmasıyla birlikte istibdat ve baskılar eskisinden daha çok artmış ve Rusya Müslümanlarının bu dönemde çıkardığı birçok gazete ve dergi birer birer kapanmaya başlamıştır. Açılan Rus meclisine Müslümanların seçilmesi de Rusları korkutmuş olmalı ki eskisinden daha da fazla baskı yapmalarına sebep olmuştur. Bu durum İsmail Gaspıralı'nın bile işlerden soğumasına sebep olduğu mektuptan anlaşılmaktadır. Ama yine de İsmail Bey yılmamış ve yılmadığı gibi Ali Merdan Bey’i de ondan etkilenmemesi için gereken nasihatleri vermeyi ihmal etmemiştir. Ayrıca İsmail Bey'in ve çıkardığı Tercüman gazetesinin ikinci ve önemli döneminin başladığını ve şahsıyla ilgili ayrıntıyı buradan öğreniyoruz. Böylece İ. Gaspıralı Tercüman gazetesini bu amaçları doğrultusunda kullanacağını ve seyahate çıkacağından bahsetmiştir. Bir de İsmail Bey, Dünya Müslümanları Kongresi düzenlemek amacıyla Kahire'ye gittiği ve orada bu amacı doğrultusunda temas ve çalışmalarda bulunmuştur. ${ }^{55}$ Ali Merdan Bey'e de bu kongreye Fransızca ve hükema-sosyolog olarak hazırlanmasını söylemiştir. Ancak bu kongre İsmail Bey hayatta iken düzenlenememiştir.

\footnotetext{
${ }^{55}$ İsmail Gaspıralı'nın Mısır seyahati hakkında ayrıntılı bilgi için bakınız: İsmail Gaspıralı, Seçilmiş Eserleri: 3. DilEdebiyat-Seyahat Yazlları. Neşre Hazırlayan: Yavuz Akpınar, Ötüken Yayınevi, İstanbul, 2008. Sayfa 453-476. Ayrıca Dünya Müslümanları Kongresi'nin önemi ve hakkında İ. Gaspıralı'nın Tercüman'da Dünya Müslümanları Kongresi konusunda yazdığı yazılar için bakınız: Ismail Gaspıralı, Seçilmiş Eserleri: 2. Fikrî Eserleri. Neşre Hazırlayan: Yavuz Akpınar, Ötüken Yayınevi, İstanbul, 2005. Sayfa 352-394.
} 
Belge 6: İsmail Gaspıralı’nın Ali Merdan Topçubaşı’na yazdı̆̆ı 14 Mart [27 Mart] 1910 tarihli mektup ve tercümesi:

\section{4 clea funaters.}

Laforau clepharr, Lacing.

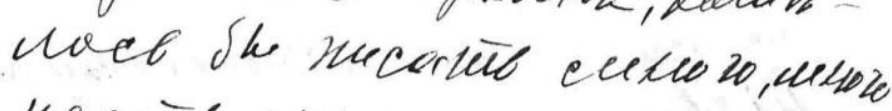
necuit. ren, dw dyboprlbe

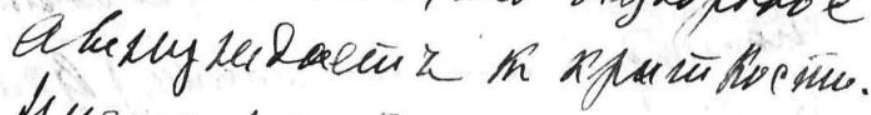
Lureva he mirnacma: scent,

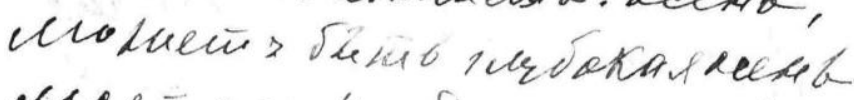

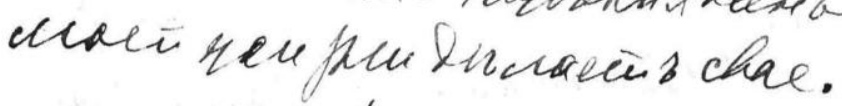

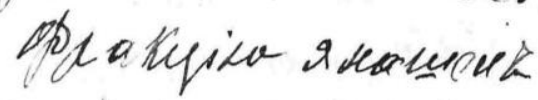

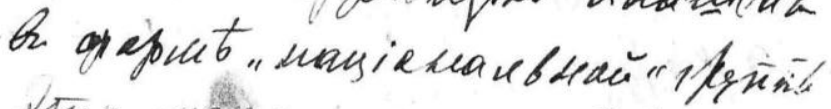

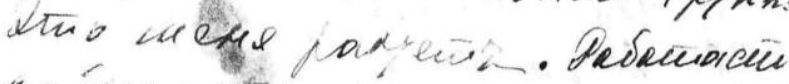

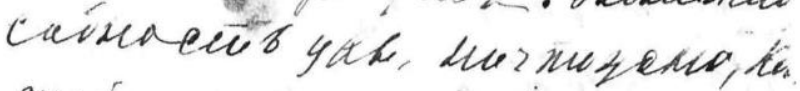
meir caviomy ujtesculer, sino

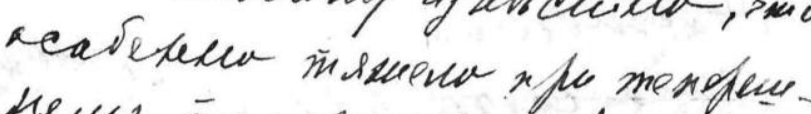
немг ñonoduesuir V.dqutur. Das naokemar nfe crumber ohflativic a

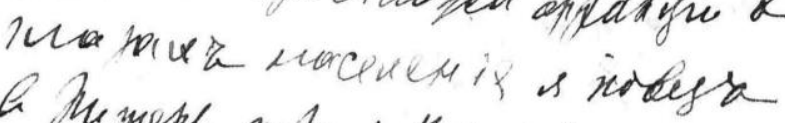

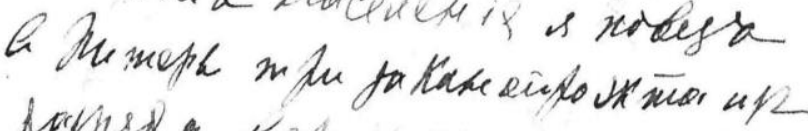

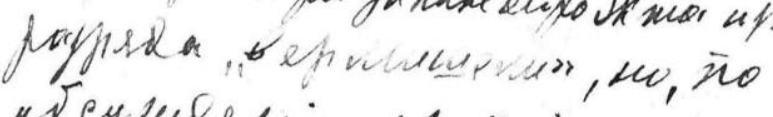

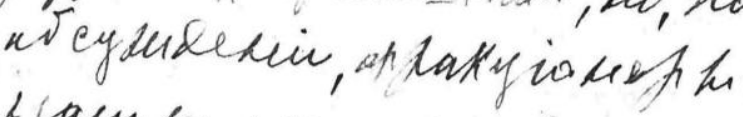

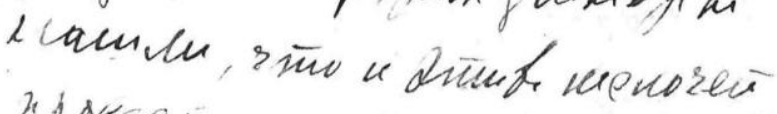
ajscec iue neg deroúdel. Lopub

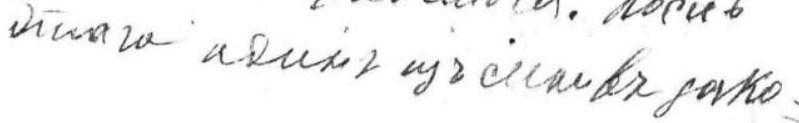

\section{ylark}

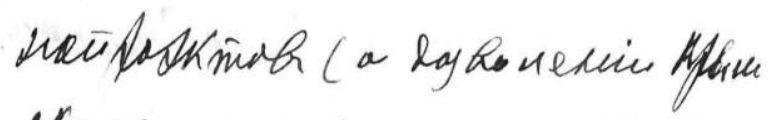

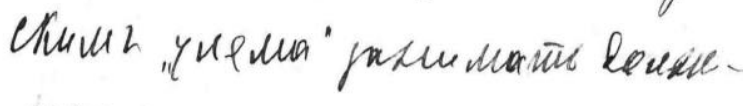

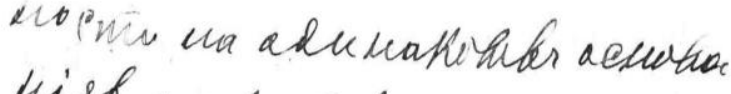

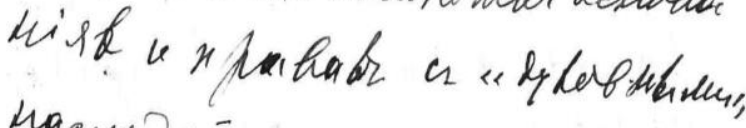

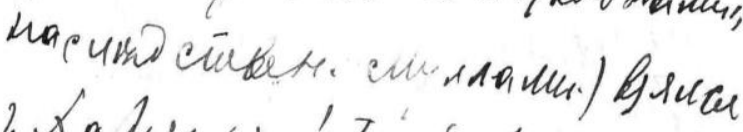

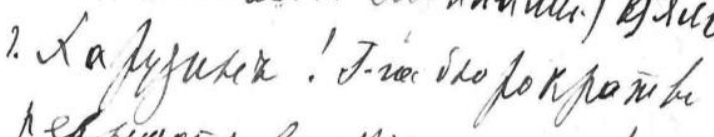

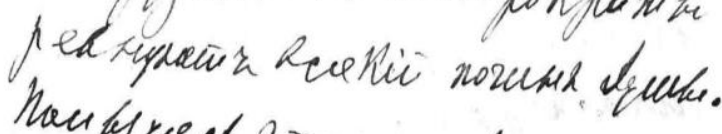

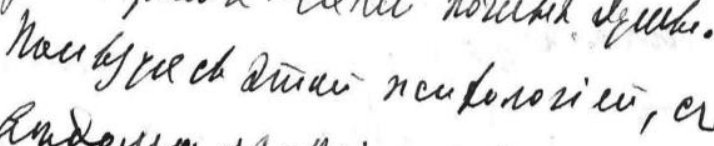

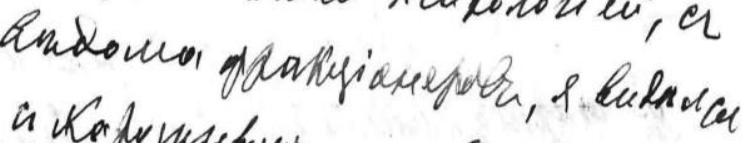

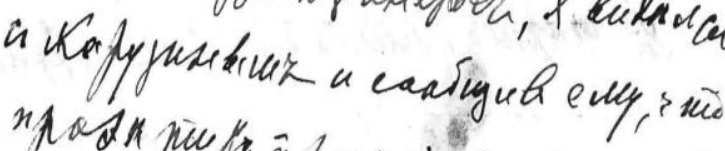

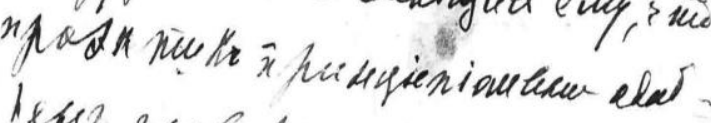
1

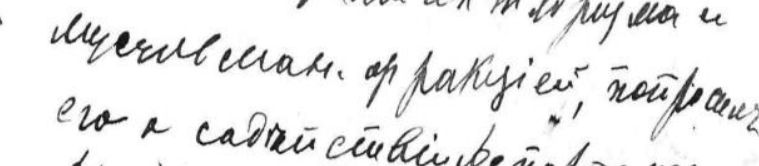

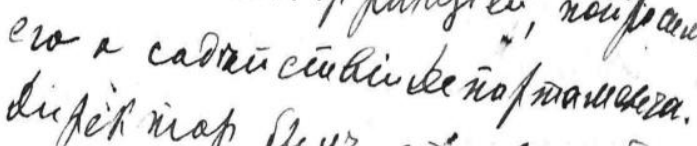

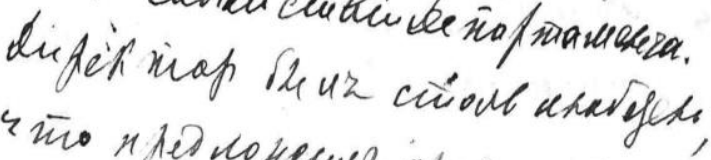

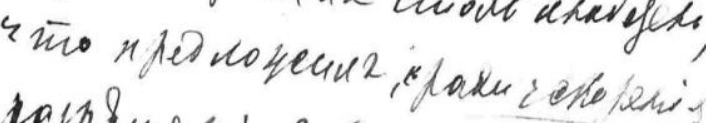

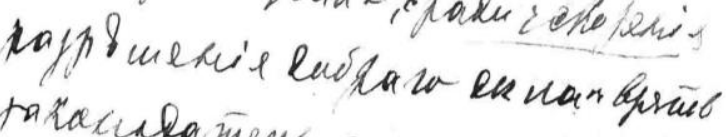

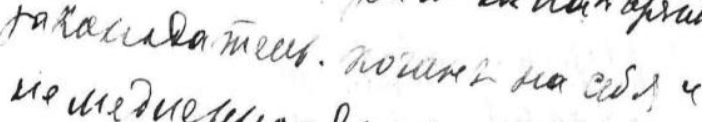

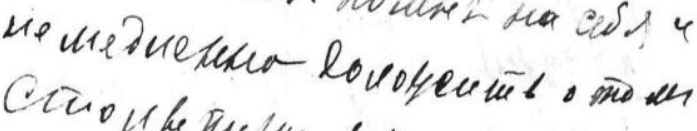

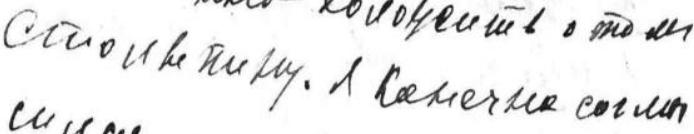
crucu, a cenalas musuy emy, iño racenerie mferenit 


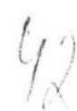

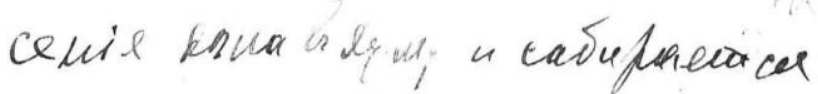
wipanumb us kor dglatign. Hetise oresca padrecus,

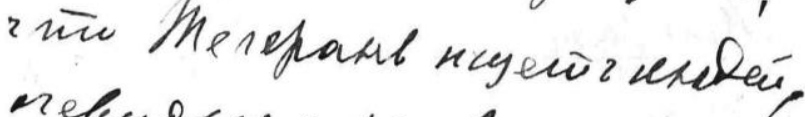

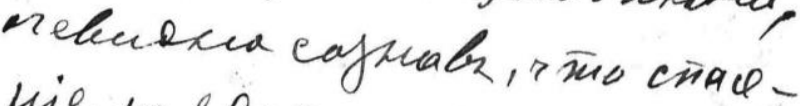
vie the bluñ nounims. Taryeds: fisk, a cradsbs. I haterto

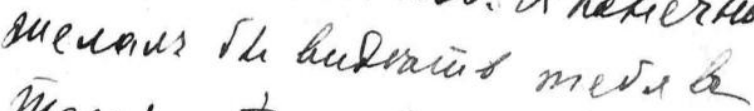
Herefinut; manar matar ñoafume

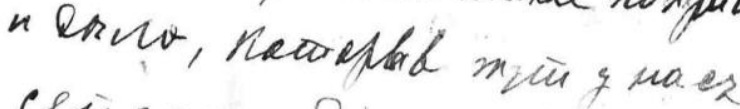

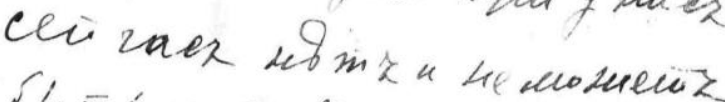

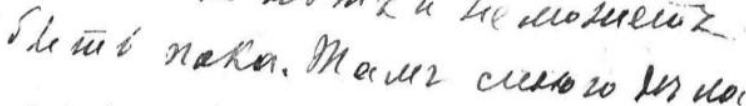

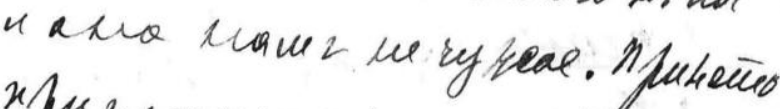

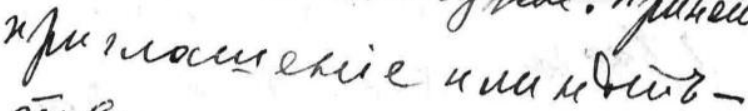
nithae muscare onvo ca borm ira dapacmum a Rly varm no. cuñocuais en. Macayeubars bio purva caure raciu whed

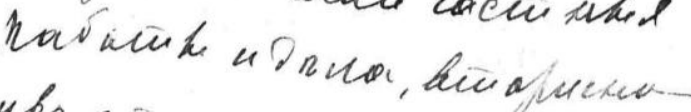

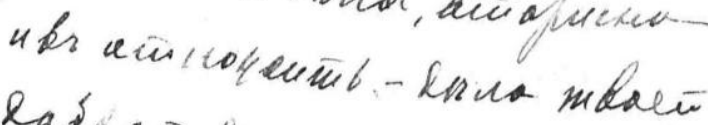
las ac disu. Hoxe new

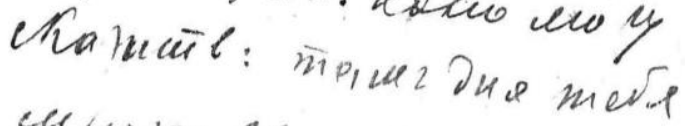

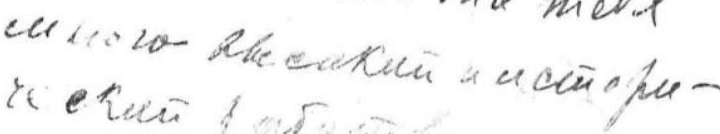

Ypone

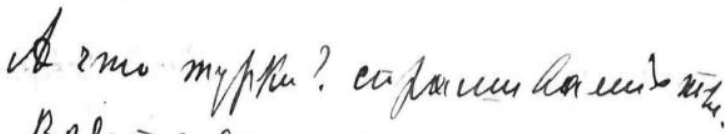

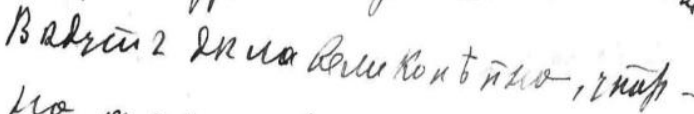

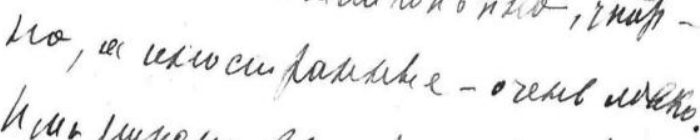

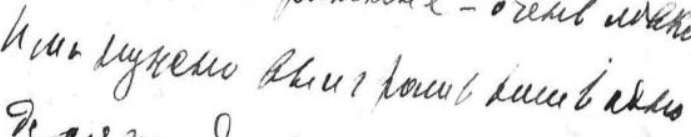
De ces munb mie cha la a aruero

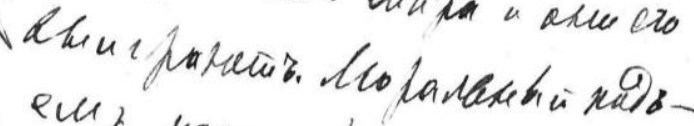

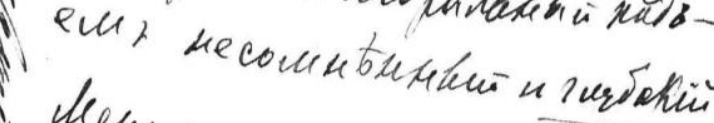

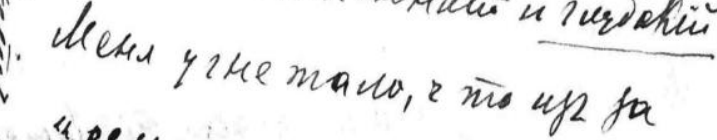
doo ga int us a yectoramues. cloily eaciryuñt merir, eña

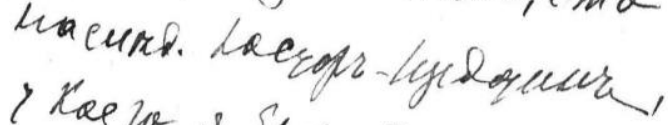
Y Kae la a Sbur ño e wa ñfa icamesira cethefte same

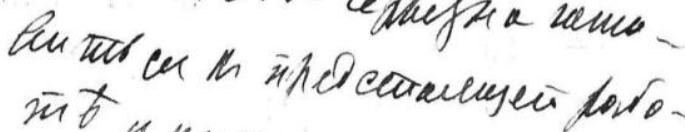

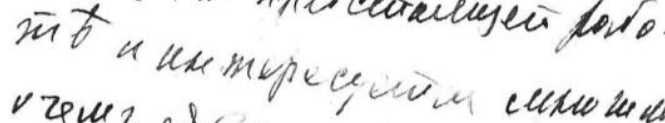

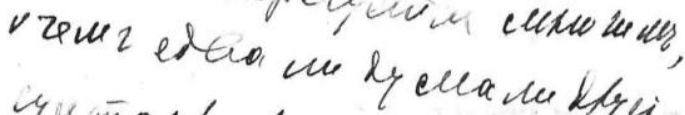

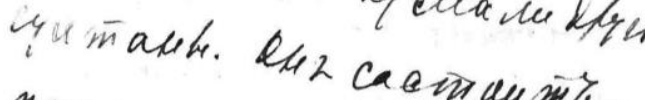

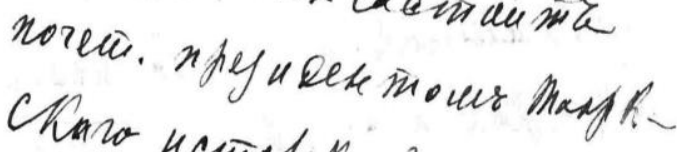

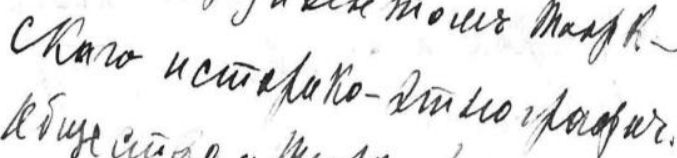

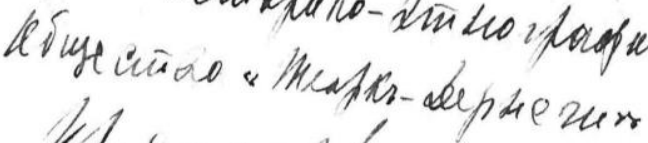

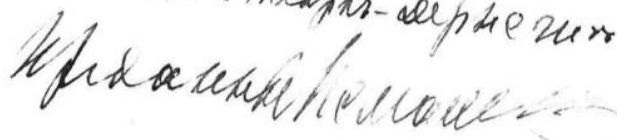


Sevgili Merdan, çok şey yazmak isterdim, yazılacak çok şey de var, ama rahatsızlı̆̆ım kısa yazmaya zorluyor. Yapacak bir şey yok: Sonbahar, belki hayatımın uzun sonbaharı, yapacă̆ını yapıyor.

Fraksiyonu "56 "millî” grup tarzında buldum. Bu beni sevindiriyor. Çalışma gücü, maalesef senin de bildiğin gibi cüzî ve bilhassa şimdiki D[evlet] Duması'nın durumunda ă̆ırdır. Halkın nazarında fraksiyonun saygınlı̆̆ını yükseltmek için ben Piter'e ${ }^{57}$ katkı kabilinden üç yasa tasarısı götürdüm, ama görüşmelerde fraksiyon mensupları bu gibi ufak tefek şeyleri dahi geçirmenin mümkün olmayacă̆ını düşünüyorlar. Bundan sonra benim yasa tasarlarımdan bir tanesini (Kırımlı "ulemanın" "ruhanî" ve nesilden nesile geçen imamlık [hüccetli molla] görevli mollalarla eşit ilke ve haklara sahip olarak görev almalarına izin verilmesi) Haruzin ${ }^{58}$ Bey ele aldı! Bürokrat b[eyefendile]r Duma'nın her türlü girişimini kıskanıyorlar. Bu psikolojiden istifade ederek ve fraksiyon mensuplarının izniyle ben Haruzin'le görüşü̈m ve ona projenin, Oktyabrizm ${ }^{59}$ liderleri ve Müslüm[an] fraksiyonun liderleri tarafindan prensip olarak uygun bulunduğunu haber vererek, bu konuda ondan bakanlı̆̆ın yardımını istedim. Yönetici o kadar nazikti ki bu hayırlı işin çözümünü hızlandırmak için yasa[ma] girişimini üzerine alarak bu işi hemen Stolıpin'e haber vermeyi önerdi. Ben, tabii ki razı oldum. Bugün de halkın, işi Duma'ya getirilmesini istediğini ve kanun için fraksiyona başvurmaya hazırlandı̆̆ını yazıyorum.

Tahran'ın insanlar araması beni çok sevindiriyor. Galiba kurtuluşun diplomat[ik] kançılaryalarda değil de insanlarda olduğunun farkına vardı. Ben tabii ki seni Tahran'da görmeyi arzu ederdim; orada öyle alan ve işler var ki burada bizde şimdilik yok ve olamaz da. Orada çok iş var ve bunlar bize yabancı değildir. Daveti, bütün iyi ve diğer sonuçlarlyla kabul edip etmemek senin şahsî meselendir. Kendi şahsî çalışmalarını ve işlerini bir kez daha yoluna koymak veya onları bir kez daha ertelemek, senin güzel gönlünün isteğine kalmış. Şunu söyleyebilirim: Orada senin için çok yüksek ve tarihî işler vardır. ${ }^{0}$ Sen, Türkler ne yaptı? diye soruyordun. Onlar işleri sebatla ve mükemmel bir surette yönetiyorlar, yabancılar ise çok ustaca. Onların, sadece on yıllık barış süreci kazanmaları gerekiyor ve kazanacaklar da. Ahlakî yükseliş tartışma götürmez ve derindir. “Osmanlıcllık” yüzünden “Türk” ün kaybolması içimi karartıyordu ama sonra sakinleştim. Daveti üzerine ziyaretine gittiğim Şehza[de] Yusuf İzzeddin'in ${ }^{61}$ önümüzdeki gelecek işlere ciddi bir şekilde hazırlandı̆̆ını ve muhtemelen diğer sultanların düşünmediği çok şeyle ilgilendiğini sana haber verebilirim. O, "Türk Derneği",62 adll Türk TarihEtnograf[ya] Cemiyeti’nin fahrî başkanıdır.

Vefalı İsmail.

$$
\text { G[ençle]re }{ }^{63} \text { selam, çocukları öpüyorum. }
$$

\footnotetext{
${ }^{56}$ Burada Devlet Duması'ndaki Müslüman Fraksiyonu kastedilmiştir.

${ }^{57}$ Piter, Petersburg şehrinin kısaltılmış ifade şeklidir.

58 Aleksey Nikolayeviç Haruzin (1864-1932): Rus devlet adamı, 1904-1908 yılları arasında Besarabya'nın genel valisi, sonra da İç İşleri Bakanlığı'na bağlı Yabancı Dinlerin Ruhanî İşler Bakanlığı'nın müdürü, İç İşleri Bakan yardımcılığı (1911) görevlerini yürütmüştür.

59 Soyüz 17 Oktyabrya “Oktyabristı" (Союз 17 октября «Октябристы») [17 Oktyabr Birliği “Oktyabrsitler”]: Rusya'da 1905-1917 y1lları arasında var olan sağcı-liberal siyasî bürokratların, toprak beylerinin ve büyük ticarî sınaî burjuvazisinin partisidir. Bu parti ılımlı-anayasal görüşlere bağlı kalarak Rusya liberalizminin sağ kanadını temsil etmiştir.

${ }^{60}$ Burada İran hükûmetinin Ali Merdan Bey’i devlet işlerinde yardım etmesi için ikinci defa davet etmeyi görüştüğü kastedilmiştir (Həsənli, 2013 11; Gasanl1, 2014: 127). Nitekim mektuptan da Ali Bey’i İran'a davet ettikleri anlaşılmaktadır.

${ }^{61}$ Şehzade Yusuf İzzeddin Efendi (1857-1916): Sultan Abdülaziz'in oğlu, 1909 yılından itibaren ise Osmanlı tahtının varisi, reformcu. Ölüm nedeni intihara bağlı kan kaybı olarak kabul edilse de, İttihatçıların onu öldürttüğü de teoriler arasındadır. Mektupta bahsedildiği gibi İsmail Gaspıralı, Şehzade Yusuf İzzeddin'in daveti üzerine İstanbul'a gider ve kendisiyle görüşür. Bu görüşmenin izlenimlerini Tercüman gazetesinin 20 Noyabr 1909/20 Zilkade 1327 tarihli 47. sayısında "Veliahd-1 Saltanat ve Hilafet huzurunda" başlığıyla yayımlamıştır (Akpınar, 2008: 332-334).

${ }^{62}$ Türk Derneği: Türk kültürünün mirasını araştırma ve propagandası amacıyla 1908 yılında kurulan bilimsel-kültürel cemiyettir. Bu cemiyete meşhur Türk, Avrupalı ve Rusyalı şarkiyatçılar ve ayrıca başta İ. Gaspıralı olmak üzere Rusya Müslümanlarından da birkaç temsilci mensup olmuştu. Bu cemiyetin kurulmasından sonra Osmanlı mensupların büyük bir kısmı Rusya Müslümanları hakkında ilk defa haberdar olmuşlardır. Daha sonra bu cemiyet kültürel-eğitimsel Türk Ocağı cemiyetine dönüştürülmüştür (Türkoğlu, 2011: 87).

${ }^{63}$ Metin bozukluğundan dolayı bu kelime tahmini olarak yazılmıştır.
} 
Görüldüğü gibi bu mektupta İsmail Gaspıralı, el verdiği ölçüde çalışmaya gayret ettiği göze çarpmaktadır. Bu yüzden de kısa da olsa hayatî önem taşıyan birçok konuya değinerek Ali Merdan Bey'i bu konularda bilgilendirmiştir. Devlet Duması'ndaki Müslüman Fraksiyonu'nun çalışmasından ve bir takım tasarıların kabulü için izlediği dâhiyane yoldan da söz edilmiştir. Ayrıca İ. Gaspıralı'nın Osmanlı ve İran'da cereyan eden olayları ne derece iyi ve yakından takip ettiği anlaşılmaktadır. Burada İran hükûmetinin çalışmak için Ali Merdan Bey’i tekrar davet ettiği de ortaya çıkmaktadır. Bir de Osmanlı'da cereyan eden Osmanlıcılık ve Türkçülük gibi iç olayları da ilgiyle ve yakından takip ettiği anlaşılmaktadır. Osmanlı'nın on yıllık barış sürecini kazanmaları gerektiği, Türklerin çalışmaları ve Şehzade Yusuf İzzeddin hakkındaki yorumu bunu en iyi şekilde göstermektedir. Bilindiği gibi Şehzade Yusuf İzzeddin Almanya'da intihar etmiş̧ (muhtemelen öldürülmüş), Osmanlı Devleti bu on yıllık barış sürecini elde edememiş ve kısa sürede girdiği Balkan ve I. Dünya Savaşı gibi yıkıcı savaşlar sonucunda tarih sahnesinden çekilmiştir. 
Belge 7: İsmail Gaspıralı’nın Ali Merdan Topçubaşı’na yazdığı 8 Avgust [21 Ă̆ustos] 1910 tarihli mektup ve tercümesi:

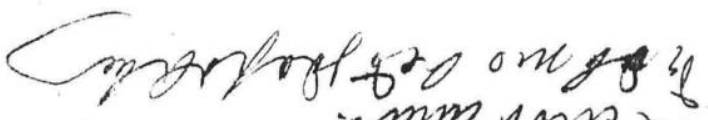
XXXIII год'

$$
\text { ismorarovin }
$$

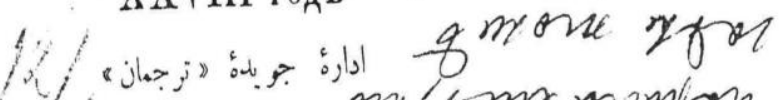

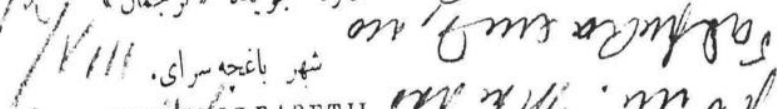

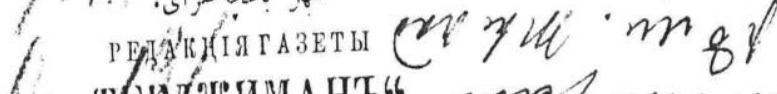

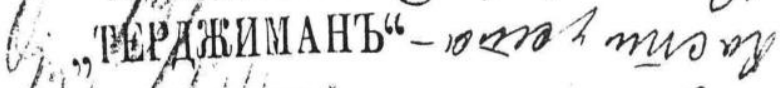

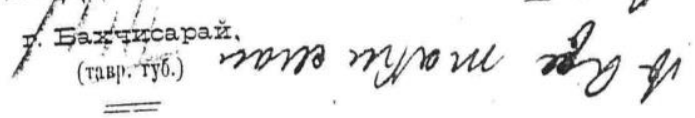
Pablyeans 19101.

Hy, ескиi Lafo seci и me

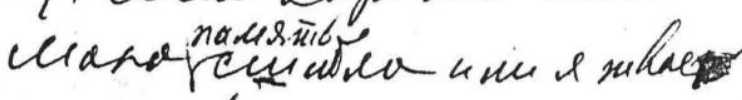

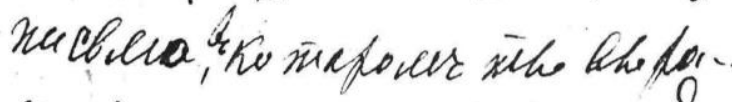

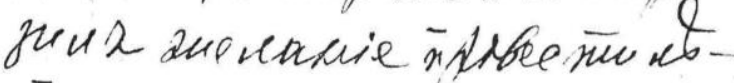

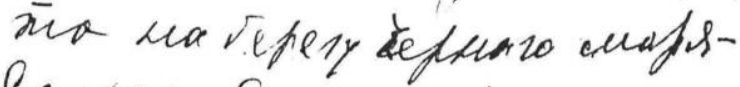

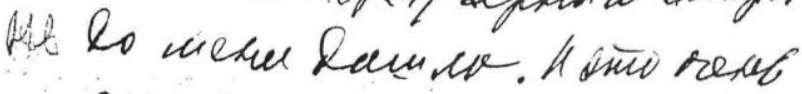

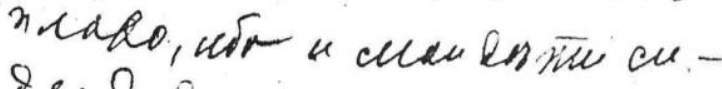
isml Rovia.

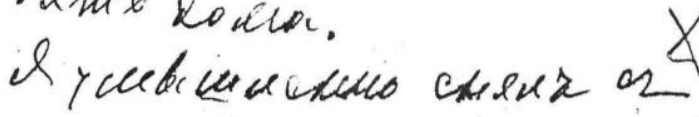
une za fo nefmeala aphaghtee

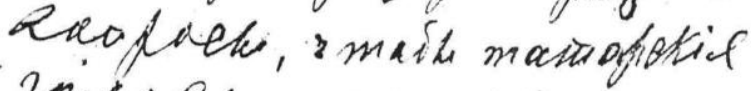
20 cakle calm nabycuma

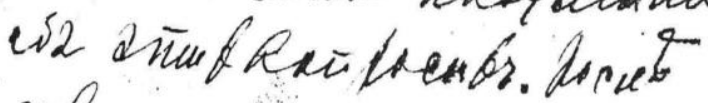

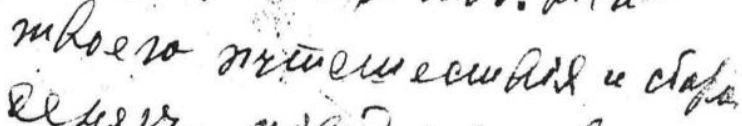
Reters, nokederie uás suras * Ey niprinoce, nako hicers

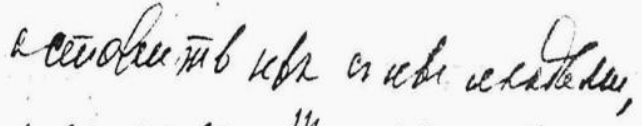

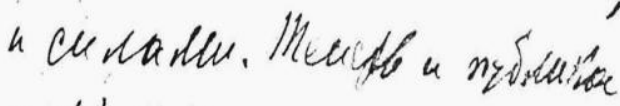
"offattyis matereu, r nios sand

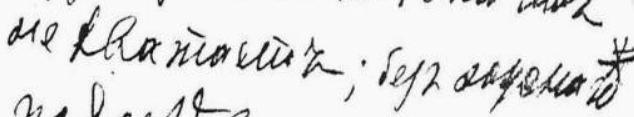
nahoiptbani1 whene uth.

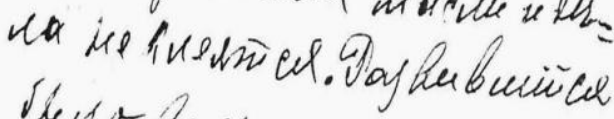

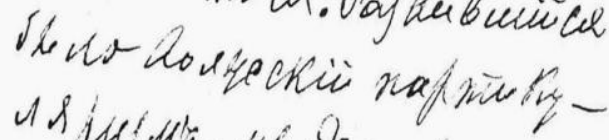

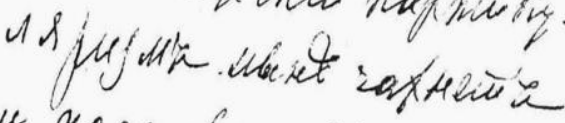
u nacenfesea the cristñeno.* I Launnur suge ñefoudaínt no tukal nuebsur astlu wo cuscue rebculy bus.

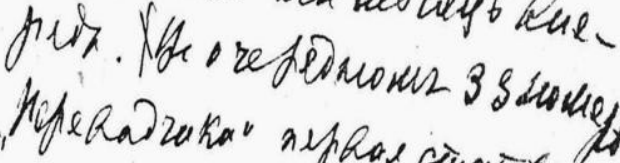

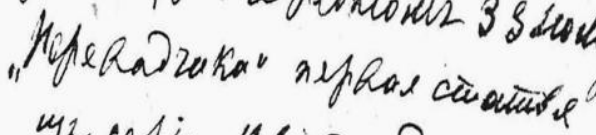

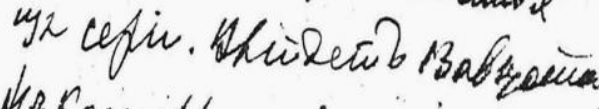

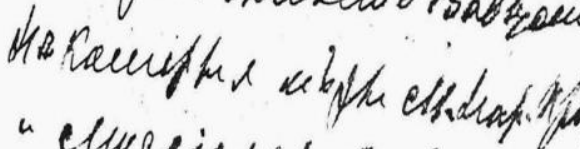

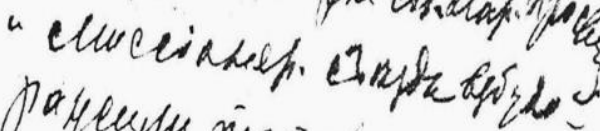

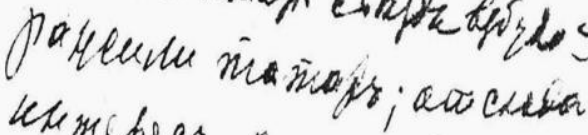

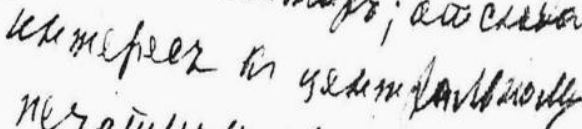

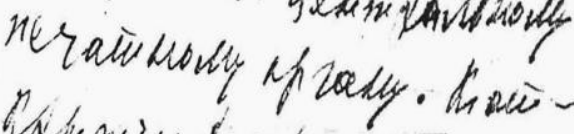

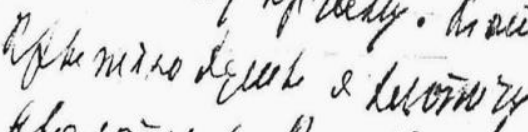

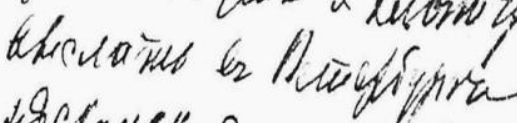
uclauktha bea mistis 
1050

Rıdvan CiTIL

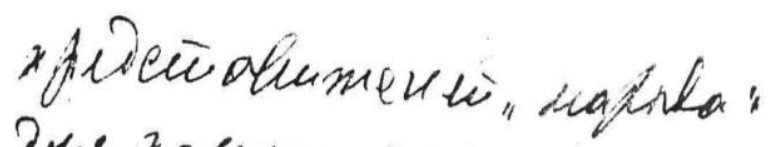

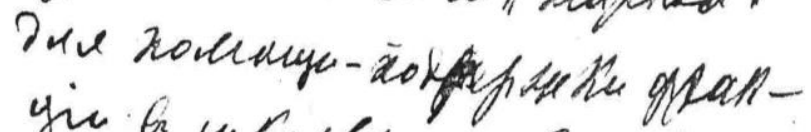

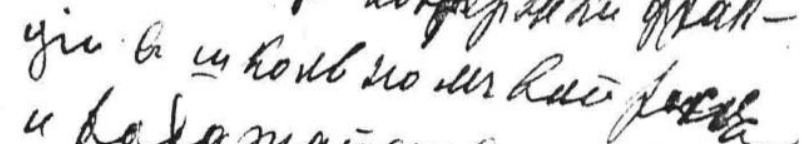

- u haka maicuba nagala da paseni aften u mitrony-

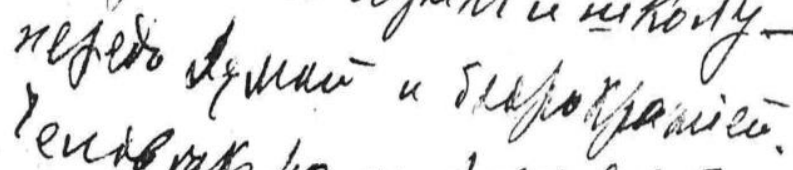
levis vath to up Jajtilis wi.

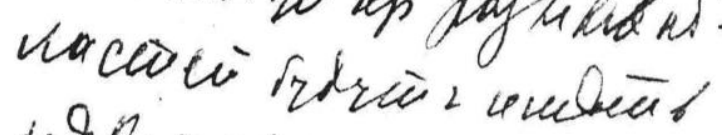
usiaumine enafias is ane Govisusis dath" soukn nadaka" a he niverthe grothyiv.

O saseñt is ma Rhiffe jogen

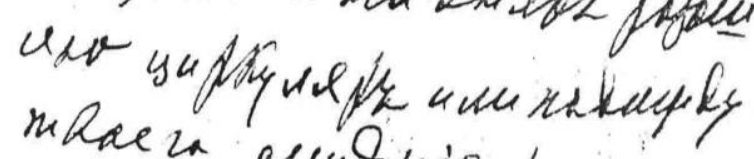
mbae ia cunt mis. tha ovent

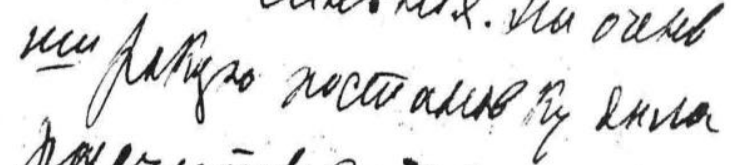
tay eru inkle sob ne rabo. Cido cenurmy by nashaur iniv: Susheindbsur do.

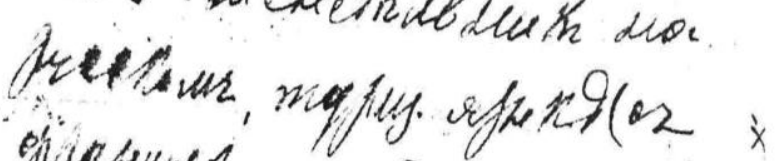

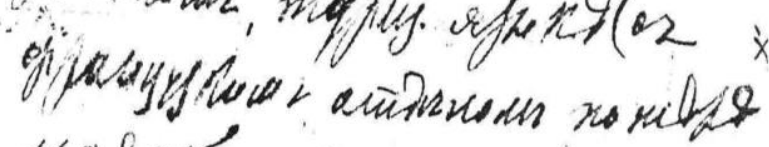

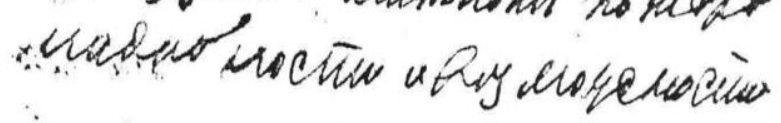

Yrod by.

Lenth. Kanuman:

: Was nalme anscuryube bustur no 18 gas

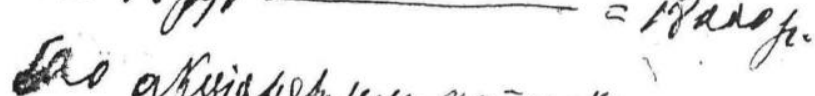

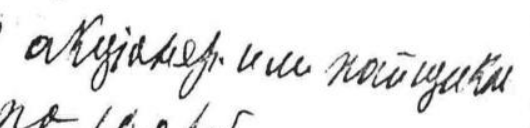

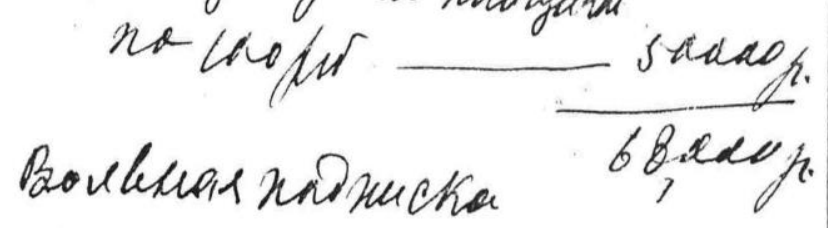

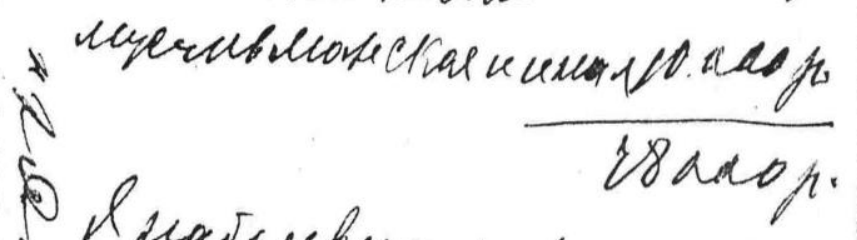

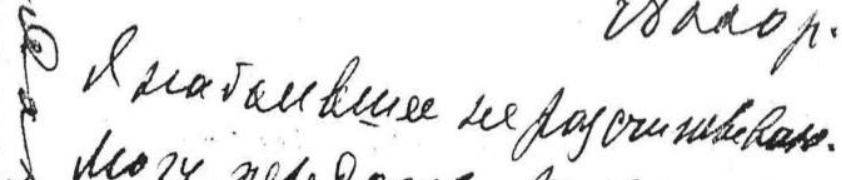

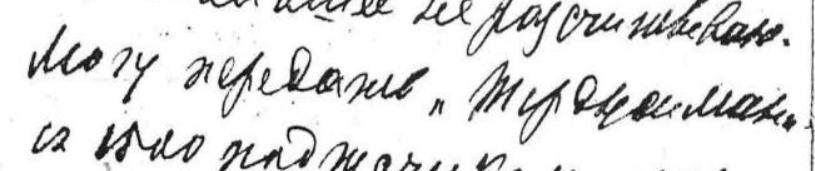

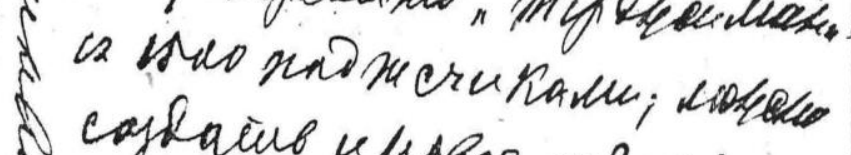

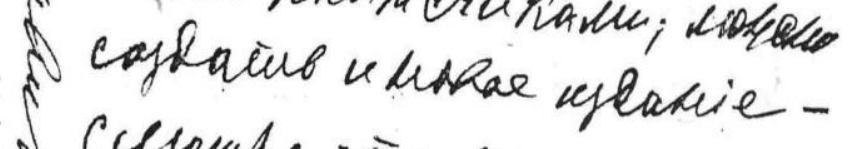

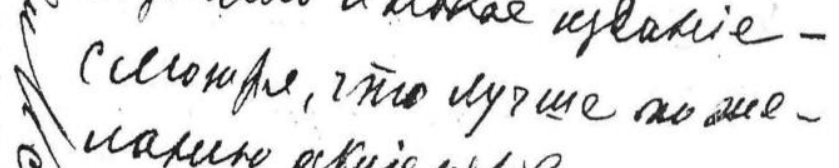

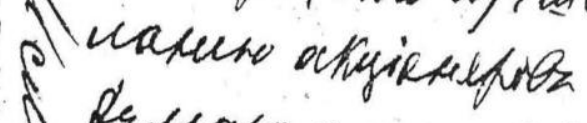

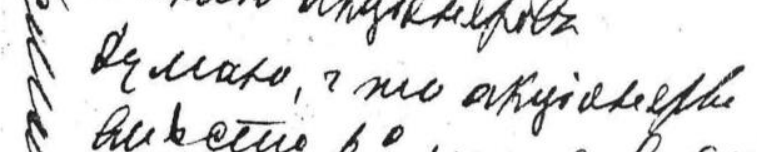

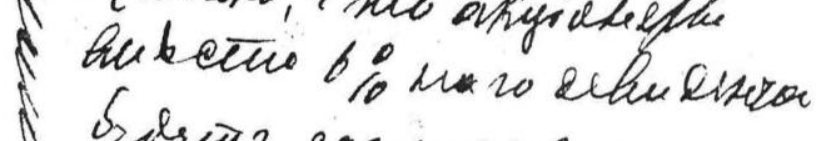
Subior cor vachla nomiroños

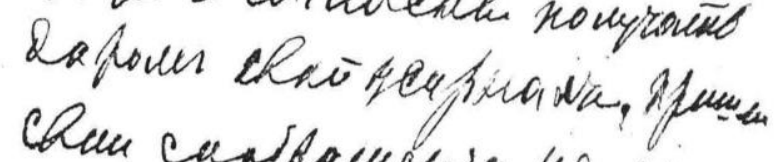

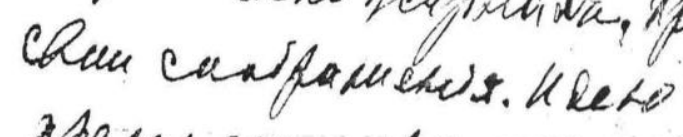

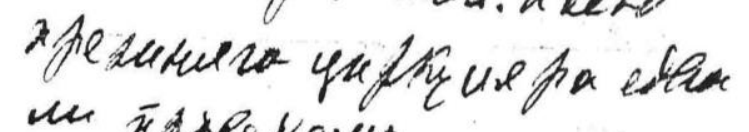
un זqurekeus.

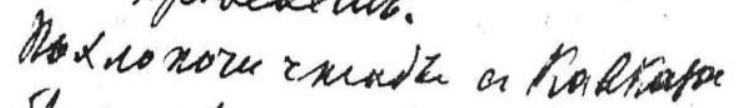

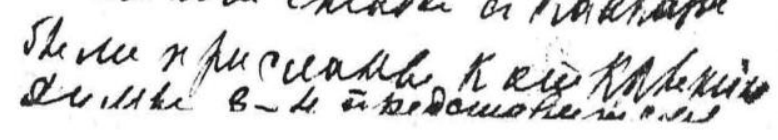
tros

TFke

Uluslararası Türkçe Edebiyat Kültür Eğitim Dergisi Sayı: 4/3 2015 s. 1022-1054, TÜRKİYE 
E azizim, ya benim hafızam gitti ya da senin; yazı Kara Deniz kıyısında geçirmek istediğini ifade eden mektubun bana ulaşmamıştır. Ve bu çok kötü oldu, zira benim çocuklarım da evde oturuyorlar.

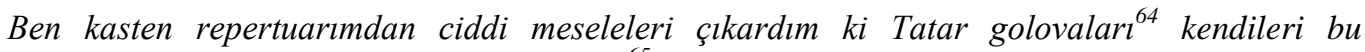
meseleler hakkında düşünsünler. Senin seyahatinden ${ }^{65}$ ve para toplamadan sonra onların davranışı beni öfkelendirdi, onları kendi insanlarıyla ve imkânlarıyla bırakmak gerekiyordu. Şimdi millet ve fraksiyon, gücün yetmediğini anladılar; düşünce ve iş gerekli biçimde desteklenmediğinde gerçekleşmiyor. Gelişti gelişecek olan İdil yöreciliği şimdilerde zayıflıyor ve elden geldikçe yardımc olacă̆ım. Biraz daha beklemek istiyordum ama senin mektubun beni ileriye götürdü. "Perevodçik"in ["Tercüman" in] siradaki 33. sayısında yazı dizisinin ilk yazısı 13 Avgust [25 A ğustos]'ta çıkacak. ${ }^{66}$ Halk Ĕ̈i [tim] B[akanlı̆̆ ]' nın ve Misyo[ner] Kongre'nin ${ }^{67}$ bazı önlemleri Tatarları telaşa düşürdü; merkezî basın organına ilgi bundandır. Duma'nın açılışına, fraksiyonu, okul meselesinde yardım-desteği sağlamak ve Duma ile bürokrasi önünde ana dil ve okul için halkın adına dilekçe vermek amacıyla birkaç onlarca "halk" temsilcisini Petersburg'a göndermeğe uğraşıyorum. Farklı bölgelerden 40 kadar temsilci sadece fraksiyonun değil "halkın sesi”" olarak manevî anlam da ifade edeceklerdir.

Gazete hakkında bugünlerde sirkülerler göndereceğim veya senin düşünceni bekleyeceğim. İşin çok geniş ortaya konuş tarzını beklememek lazım. Şu dakikada şunu düşünüyorum: Rusça-Türk[çe] haftalık dergi (lüzum ve imkâna göre Fransızca bölümle).

$$
\begin{aligned}
& \text { Fiyatı } 6 \text { rub.[le] } \\
& \text { Tem[el] sermaye: } \\
& 18 \mathrm{rub.[leden]} \mathrm{tekrar} \mathrm{abone} \mathrm{olanlar} 1000 \text { kişi } \\
& 100 \mathrm{rub} .[\text { leden] } 500 \text { hissedar[lar] veya paydaşlar }
\end{aligned}
$$

Müslüman veya diğerlerin serbest aboneliği

$$
=18000 \mathrm{r} \text {. }
$$

$\underline{50000 r .}$

$68000 r$.

$10000 \mathrm{r}$.

Daha fazlasını beklemiyorum. 1500 aboneli "Tercüman"l devredebilirim; hissedarların isteklerine göre hangisi iyi olduğuna bakılarak yeni bir yayın da oluşturabiliriz.

Hissedarların, \%6 temettü yerine kendi dergilerini bedava almaya razı olacaklarını düşünüyorum. Kendi düşüncelerini gönder. Eski sirküler fikrini kabul ettirmek çok zor.

Duma'nın açılışına Kafkasya'dan 8-9 temsilcinin gönderilmesi için uğraş.

Vefall Ismail

[P.S.] Gene de, benim kemiklerim eskidi. Sen cesaret veriyorsun ama ylllar da susmuyorlar.

Hepiniz să̆lıcakla kalın.

Görüldüğü gibi bu mektupta İsmail Gaspıralı ile Ali Merdan Topçubaşı Rusya Müslümanları için ellerindeki imkânlarla gösterdiği çaba ve gayret açıkça anlaşılmaktadır. Bunu da kimi seyahate çıkarak kimi de sirküler-bildiriler çıkarmayı planlayarak ve gazetede yazılar yazarak yapmaktadır. Meclisteki Müslüman Fraksiyonu’nun çalışmaları ve bunlara yapılan

\footnotetext{
${ }^{64}$ Golova: Belediye başkanı.

${ }^{65}$ Burada A. M. Topçubaşı'nın 1909 yılının yazında İdil-Ural bölgesine yaptığı seyahat kastedilmektedir.

${ }^{66}$ Burada sözü edilen 13 Avgust 1910/20 Şaban 1328 tarihli 33. sayıdaki "Unutmayalım” başlıklı yazıdır. Bu yazıda İsmail Gaspıralı özetle, son yıllarda yaşanan gelişmelerden, Rusya Müslümanlarının son yıllarda elde ettiklerinden ve girilen yeni dönemle yapılacakları hakkındaki konulara değinmiştir. Ancak bu yazının devamına Tercüman gazetesinin diğer sayfalarında rastlanmamıştır.

${ }^{67}$ Misyoner Kongre: 13-26 Haziran 1910 tarihlerinde Kazan'da düzenlenmiştir.
} 
destek de gün yüzüne çıkmaktadır. O dönemde Müslüman Fraksiyonun yayın organına olan ihtiyacı iyi bilenlerden biri yine İsmail Bey olmuş ve o ortamda bu yayın organın çıkartılamadığı için İ. Gaspıralı Tercüman gazetesini devretmeye dahi hazırdır. Ayrıca İsmail Bey Rusça-Türkçe ve lüzum ile imkâna göre Fransızca bölümle haftalık dergi çıkarmanın hesaplarını bile yapmıştır. Ancak bu dergiyi çıkartamamıştır.

Bir de İsmail Bey’in bu mektupta, Tercüman gazetesinin 33. sayısında çıkacak dediği yazı dizisinin ilk yazısı 13 Avgust [26 Ağustos]'ta "Unutmayalım” başlığıyla ve sadece bir yazı yayımlanmıştır. Bu yazıda İsmail Bey o dönemi ve Rusya Müslümanlarının çalışmalarını özetlediği için bu yazıyı Arap harflerinden Latin harflerine aktararak buraya almaya uygun gördük.

\section{Unutmayalım $^{68}$}

13 Avgust 1910 / 20 Şaban 1328, [26 Ağustos 1910] Sayı: 33, Sayfa: 1-2

Bir seneden ziyadedir ki matbuatımız sönük ve salkın görünüyor. Hayatî ve siyasî meselelerimizden bahisler pek nadir görülüyor. Bu salkınlık, bu ümitsizlik bütün cemaatimize musallat olmuş teessüflü hâldir, matbuata aks ettiği tabiîdir. Lâkin mücahede-i hayatiyenin birinci safinda bulunan muharrirlerin ve iş kişilerinin cümleden ziyade çıdam, mukavemet ve himmet buyurmakları şeref ve haysiyetlerine bağlı vazifelerdir.

Bu salkınlık ve ümitsizlik neden geliyor? Umum Rusya'nın müpteli olduğu aks-i hareket ve ümitsizliktendir demek mümkündür. Lâkin biz böyle demek istemiyoruz. Rusya'nın milyonlarca Müslümanları Rusya'nın hareketlerinden, ümit ve arzularından bihaber kaldılar, ne olduğunu ne için olduğunu anlamadılar, bir borandır, geldi geçti. Fakat asarı bütün bütün kalmadı değildir. Bu asar-1 inkılâp ya ki boran semeratı Kırgız Kazak'tan maada cümle Müslümanların hâl ve hayatını hayli ileriye sevk etti.

Buna şükür etmeli. Çünkü bu günkü hak ve hukukumuz 17 Oktabr [30 Ekim] manifestinden evvelkine göre meydancadır. Mukaddemce ağza almak mümkün olmayan kelimeler bugün lügat-1 umumîden olmuştur. Başa gelmeyen fikirler uzun uzadı müzakere ile karye çetlerine kadar yetiştiler. Edebiyat bire beş ilerledi. "Bir" olan gazetemiz bugün beş altı oldu ve daha ziyade kâr ve kesbimiz "Siyasi Dersler" görüp geçirdiğimizdir. 1905 'te 1906 ve 7'de büyük ümitler ve arzular ile dolmuş idik. "Olsun" demek ile olur biter zannında bulunanlar az değil idi. Kesb-i hukuk ve saadet ve terakkiye nailiyet tedricen vücut bulduğunu ve olsun ile değil tırmanıp çırmanıp uzun uzadı çalışmak ile meydana çıkacağını anlayanlarımız bugün çoktur. Mamafih arzu ve ümitlerimiz vücut bulmadılar ise bunları unutmak, hatırdan çıkarmak lâzım gelmez. Eğer ümit ve arzularımız rast ve doğru ve nâf’i iseler bunları taşlamak, terk etmek caiz değildir. Bilâkis bunları gönlümüzün en nazik, en aziz köşesinde muhafaza etmeliyiz. Dün vücuda getiremediğimizi bugün, bugün mümkün olmayanı erteye ve daha erteye kaldırmalı. Lâkin meram, arzu ve mesleği bırakmamalı, taşlamamalı. Bunları hıfz etmek, ara sıra bunlar ile efkâr-1 umumiyeyi kozgamak, uyandırmak matbuatın, edebiyatın vazifesidir.

Üç beş sene evvelki devremizden kalma hayli meram ve arzular vardır. İttifak-1 Müslimin namıla maruf hizb-i millî, Devlet Duması'nda Müslüman vekillerin ahaliye mütenasip derecede artırılması, idare-i şer'iyelerin hukukları arttırılıp, sslah edilmesi, İslâm mekteplerine ve lisanımıza iktiza-i zaman hukuk verilmesi ve terakki yollarını açılması, Peterburg'da Rusça-Türkçe ve kısmen Fransızca bir gazetenin tesis edilmesi ve bazı sair meramlarımız bir gün bir saat unutulmamalıdır.

"Bu şeylerin vakti değil" gibi bir itiraz olabilir. Bu şeylerin unutulması, müzakereden düşürülmesi vakte değil, kendimize taalluk eder, işlenmesi, yürütülmesi vakitten ziyade yine kendimize merbuttur. bizimdir.

İttifakın nizamnamesi tasdik edilmedi. Tebdilen ikincisini vermek Çuvaşların vazifesi değildir,

\footnotetext{
${ }^{68}$ Bu yazı Prof. Dr. Yavuz Akpınar'ın Tercüman gazetesi koleksiyonundan temin edilmiştir.
} 
Mektep ve idare-i şer'iyeler işini kozgamak nizamname layihası tertip ederek ya hükûmet ya Duma vasıtasıyla bir gün evvelce meydana çıkarmak bizlere borçtur.

4. Duma saylavları, intihap zamanı ay ve ay yaklaşıyor. Kırgızların, Türkistanilerin tamamen vekilsiz ve koca Kafkazya'nın iki vekil ile kalmaması hususta fikir yürütmek ikdam ve teşebbüs kılmak boynumuza yüklenmiş, zamanımızca gerek iştir.

Dostlarımız bilmeyip, düşmanlarımız belki kasten aleyhimizde birçok söz ve tasavvur yürüttükleri malûm. Yalnız Misyonerler İçtimaı'ndan anlaşılanı kâfidir. Bunları tashih ve ret, hakikati beyan ve müdafaa, gereklerimizi arz ve talep etmek için Peterburg'da bir gazetemiz bulunmak gerek. Tatarca özümüz yazıp özümüz okuduğumuz reddiyelerden, itiraz ve arzulardan Rusya'nın ve dünyanın haberi olmayıp kalıyor. Varlığımız-yokluğumuz anlaşılmıyor.

Bir, belki iki sene geçti. Rahatlandık, mümkün ile nâ-mümkünü anladık bildik. Artık tekrar işe başlayalım, kardeşler!

Makarya Pazarı ve cemiyeti dağılıyor. Güz geliyor. Herkes pazardan, bağ bahçe ve daladan kışlık yurtlarına kaytıyor. Lâzım gelen, mümkün olan müzakereleri edip işe bakmalıdır. Kim bakacak?

İnsan olan herkes.

Otuzdan ziyade Cemiyet-i Hayriyelerimiz ve terakkiyün ve ya ki maarif cemiyetlerimiz mevcut, oldukça işleyip geliyorlar. Rusya ve Kafkas Müslümanlarının uleması, ağniyası, şurefası, urefası bu cemiyetlerin azaları bulunduğu malûmdur. Birçok senelerden beri ettikleri ianeleri, hayır ve hasenatları meydandadır. Şimdi bunların bu hürmetli efendilerin maarif meselesine büyük himmet edecekleri anlaşılıyor. Mektebi olmayan Cemiyet-i Hayriye yoktur. Binaenaleyh Oktabr'da Devlet Duma'sı açıldı̆̆ ile müzakere başlanıp tahsil-i umumî ve mektep nizamı bakılacağından bu cemiyetler Fraksiyamızın imdadına ve sair fraksiyalara arz-1 meram etmeye birer ikişer murahhas gönderecekleri söyleniyor. Bizim Kırım Cemiyet-i Hayriyeleri urefadan, ulemadan, ağniyadan birer adam seçip Peterburg'a gönderecekler imiş.

Muvaffakiyetlerini temenni ederiz.

\section{Sonuç}

XX. yüzyılın ilk çeyreği, Rus esareti altında yaşayan Rusya MüslümanlarınınTürklerinin en önemli ve hareketli dönemlerinden biri olmuştur. $\mathrm{Bu}$ süre zarfında kısmî serbestlik, savaşlar, bağımsız cumhuriyetler kurulmuş ve tekrar esaret günleri yaşanmıştır. En önemlisi de Rusya Müslümanlarının-Türklerinin önde gelenleri, halklarının daha iyi bir hayatı için canla başla, hayatları pahasına çok çetin mücadeleler vermişlerdir.

Burada yayımladığımız mektuplar, 1904-1910 yılları arasında Rusya Müslümanlarının durumunu, mücadelesi ve onların önde gelen halkçı, maarifçi önderlerinden olan İsmail Bey Gaspıralı ile Ali Merdan Bey Topçubaşı’nın faaliyetlerin bir kısmını ve ilişkilerinin bilinmeyen bazı yönlerini yer yer en ince ayrıntılarla gün yüzüne çıkarmaktadır.

\section{Kaynaklar}

AKPINAR, Y. (1994). Azerî Edebiyatı Araştırmaları. İstanbul: Dergâh Yayınları.

AKPINAR, Y. (2005). İsmail Gaspıralı, Seçilmiş Eserleri: 2, Fikrî Eserleri. İstanbul: Ötüken Yayınevi.

AKPINAR, Y. (2008). İsmail Gaspıralı, Seçilmiş Eserleri: 3 Dil-Edebiyat-Seyahat Yazıları. İstanbul: Ötüken Yayınevi.

AKPINAR, Y. (2010). İsmail Gaspıralı'nın “Akgül Destesi” Adlı Bibliyografik Eseri. Türk Dünyası Dil ve Edebiyat Dergisi, 29, Ankara.

AKPINAR, Y. (2013). Çağdaş Türk Edebiyatları-I. Eskişehir: Anadolu Üniversitesi, Açık Öğretim Fakültesi Yayınları. 
AKPINAR, Y. (2014). İsmail Gaspıralı, Seçilmiş Eserleri: 1, Roman ve Hikâyeleri. İstanbul: Ötüken Yayınevi.

ALTSTADT, A. L. (1992). The Azerbaijani Turks. Power and Identity under Russian Rule. California: Hoover Institution Press, Stanford University, Stanford.

AŞIRLI, A. (2009). Azərbaycan Matbuatı Tarixi (1875-1920). Bak1: "Elm və Təhsil".

БЕЛЯЕВА, Л. Н., ЗИНОВЬЕВА, М. К., НИКИФОРОВ, М. М. (1958-1961). Библиография периодических изданий России 1901-1916, Том 1-4. Ленинград: Министерство Культуры РСФСР Государственная Ордена Трудового Красного Знамени Публичная Библиотека имени М. Е. САЛТЫШВА-ЩЕДРИНА.

BEŞİKÇİĞLLU, B. M. (2008). İşad Gazetesinin 1907-1908 Yıllarının Kronolojik Fihristi. Yayımlanmamış Yüksek Lisans Tezi, İzmir: Ege Üniversitesi, Sosyal Bilimler Enstitüsü.

ÇITIIL, R., NECEFOĞLU, H. (2014). İsmail Gaspıralı'nın Neşredilmemiş Bazı Mektupları. Ege Üniversitesi Edebiyat Fakültesi Türk Dili ve Edebiyatı Araştırmaları Dergisi, 23, İzmir.

DEVLET, N. (1999). Rusya Türklerinin Millî Mücadele Tarihi (1905-1917). Ankara: Türk Tarih Kurumları.

HABLEMITOĞLU, Ş., HABLEMITOĞLU, N. (1998). Şefika Gaspıralı ve Rusya'da Türk Kadın Hareketi (1893-1920). Ankara.

http://www.crimea.ru (son erişim tarihi: 15.04.2015)

https://ru.wikipedia.ru (son erişim tarihi: 15.04.2015)

HӘSəNLİ, C. (2013). Tarixi Şəxsiyyətin Tarihi. Olimərdan bəy Topçubaşov. Bakı: Azəbaycan Diplomatik Akademiyas1.

ГАСАНЛЫ, Д. (2014). Али Мардан-Бек Топубашев, Жизнь За Идею. Москва: Издательство Флинта, Издательство Наука.

İMANOV, V. (2003). Ali Merdan Topçubaşı (1865-1934). Lider Bir Aydın ve Bağımsız Azerbaycan Cumhuriyeti 'nin Temsili. İstanbul: Boğaziçi Üniversitesi Yayınevi.

ИСХАКОВ, С. М. (2007). Первая Русская Революичя И Мусульмане Российской Империи. Москва: Издательство “Социально-политическая МЫСЛЬ”.

ИСХАКОВ, С. М. (2012). А. М. Топчибаши. Документы из личных архивов. 1903-1934. Москва: Издательство "Социально-политическая МЫСЛЬ”.

ИСХАКОВ, С. М. (2015). Настал Момент... Предать Огламению. Азербайджанская Эмигразия В Письмах, Запиках, Телеграммах 1920-1937 г2. Москва: Издательство ИКАР.

KHALID, A. (1998). The Politics of Muslim Cultural Reform. Jadidism in Central Asia. Berkeley Los Angeles London: University of California Press.

KURAT, A. N. (1966). Kazan Türklerinin "Medeni Uyanış" Devri (1917 Yılına Kadar). Ankara Üniversitesi Dil ve Tarih-Coğrafya Fakültesi Dergisi, Cilt XXIV, Sayı: 3-4. TemmuzAralık.

ÖZKAYA, Y. (2011). Ahmet Ağaoğlu'nun Hüseyinzade Ali Bey’e Mektupları. Türk Yurdu, Nisan, Cilt: 31, Say1: 284 (100. Y1l Özel Say1).

REMIYEF, İ. (1926). Vakitli Tatar Matbuatı (Albom) 1905-1925. Kazan: Gajur Basmas1.

RORLICH, A. A. (1986). The Volga Tatars. A Profile in National Resilience. California: Hoover Institution Press, Stanford University, Stanford.

TÜRKYILMAZ, S. (2008). Şark-i Rus Gazetesi. Ege Üniversitesi Edebiyat Fakültesi Türk Dili ve Edebiyatı Araştırmaları Dergisi, Ocak-Haziran 2008, XIV. Cilt, No: 1.

ZENKOVSKY, S. A. (1983). Rusya'da Pan-Türkizm ve Müslümanlık. (çev. Prof. Dr. İzzet Kantemir). İstanbul: Üçdal Neşriyat. 